University of Nebraska - Lincoln

DigitalCommons@University of Nebraska - Lincoln

\title{
Facile Purification of Milligram to Gram Quantities of Condensed Tannins According to Mean Degree of Polymerization and Flavan-3-ol Subunit Composition
}

\author{
Ron H. Brown \\ University of Reading \\ Irene Murray-Harvey \\ University of Reading, i.mueller-harvey@reading.ac.uk \\ Wayne E. Zeller \\ USDA-ARS, wayne.zeller@ars.usda.gov \\ Laurie Reinhardt \\ USDA-ARS, laurie.reinhardt@ars.usda.gov \\ Elisabetta Stringano \\ University of Reading \\ See next page for additional authors \\ Follow this and additional works at: https://digitalcommons.unl.edu/usdaarsfacpub
}

Brown, Ron H.; Murray-Harvey, Irene; Zeller, Wayne E.; Reinhardt, Laurie; Stringano, Elisabetta; Gea, An; Drake, Christopher; Ropiak, Honorata M.; Fryganas, Christos; Ramsay, Aina; and Hardcastle, Emily E., "Facile Purification of Milligram to Gram Quantities of Condensed Tannins According to Mean Degree of Polymerization and Flavan-3-ol Subunit Composition" (2017). Publications from USDA-ARS / UNL Faculty. 1773.

https://digitalcommons.unl.edu/usdaarsfacpub/1773

This Article is brought to you for free and open access by the U.S. Department of Agriculture: Agricultural Research Service, Lincoln, Nebraska at DigitalCommons@University of Nebraska - Lincoln. It has been accepted for inclusion in Publications from USDA-ARS / UNL Faculty by an authorized administrator of DigitalCommons@University of Nebraska - Lincoln. 


\section{Authors}

Ron H. Brown, Irene Murray-Harvey, Wayne E. Zeller, Laurie Reinhardt, Elisabetta Stringano, An Gea, Christopher Drake, Honorata M. Ropiak, Christos Fryganas, Aina Ramsay, and Emily E. Hardcastle 


\title{
Facile Purification of Milligram to Gram Quantities of Condensed Tannins According to Mean Degree of Polymerization and Flavan-3-ol Subunit Composition
}

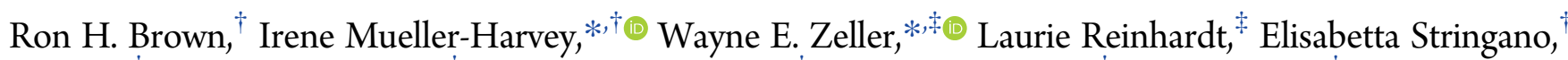
An Gea, ${ }^{\dagger}$ Christopher Drake, ${ }^{\dagger}$ Honorata M. Ropiak, ${ }^{\dagger}$ Christos Fryganas, $^{\dagger}$ Aina Ramsay, ${ }^{\dagger}$ and Emily E. Hardcastle*

${ }^{\dagger}$ School of Agriculture, Policy and Development, University of Reading, P O Box 236, Reading RG6 6AT, United Kingdom

${ }^{\ddagger}$ U.S. Dairy Forage Research Center, Agricultural Research Service, U.S. Department of Agriculture, 1925 Linden Drive, Madison, Wisconsin 53706, United States

Supporting Information

ABSTRACT: Unambiguous investigation of condensed tannin (CT) structure-activity relationships in biological systems requires well-characterized, high-purity CTs. Sephadex LH-20 and Toyopearl HW-50F resins were compared for separating CTs from acetone/water extracts, and column fractions analyzed for flavan-3-ol subunits, mean degree of polymerization (mDP), and purity. Toyopearl HW-50F generated fractions with higher $\mathrm{mDP}$ values and better separation of procyanidins (PC) and prodelphinidins (PD) but required a prepurification step, needed more time for large scale purifications, and gave poorer recoveries. Therefore, two gradient elution schemes were developed for CT purification on Sephadex LH-20 providing 146-2000 mg/fraction. Fractions were analyzed by thiolysis and NMR spectroscopy. In general, PC/PD ratios decreased and $\mathrm{mDP}$ increased during elution. ${ }^{1} \mathrm{H}$ NMR spectroscopy served as a rapid screening tool to qualitatively determine CT enrichment and carbohydrate impurities present, guiding fractionation toward repurification or ${ }^{1} \mathrm{H}-{ }^{13} \mathrm{C}$ HSQC NMR spectroscopy and thiolysis. These protocols provide options for preparing highly pure CT samples.

KEYWORDS: proanthocyanidins, Sephadex LH-20, Toyopearl HW-50F, nuclear magnetic resonance, thiolysis, batch chromatography

\section{INTRODUCTION}

As a class of plant polyphenols, condensed tannins (CTs; syn. proanthocyanidins) (Figure 1) have received considerable attention due to their human health benefits, ${ }^{1}$ their ability to improve the economic impact of livestock production in terms of farming efficiency and animal health, and can thus contribute to environmental and sustainability aspects of agriculture. ${ }^{2-5}$ Due to this potentially significant impact of CTs on food security, studies of these effects require accurate information on CT content and composition of plants or isolated CTs to elicit optimal ruminant productivity and minimize environmental impact. Through this work, potential forage targets may be identified to optimize their content and composition.

It is generally accepted that the beneficial effects CTs have on ruminant productivity stem from their interactions with proteins, since CTs in forages can modulate protein utilization in ruminants, impact the forage ensiling process, and exert positive downstream environmental effects. Interest is growing in using CTs isolated from plants for in vitro studies that evaluate protein-binding, fermentation, anthelmintic, antimicrobial, anti-inflammatory, and immunological effects. ${ }^{6-10}$ In addition, some nutritional and even feeding trials with small animals could also be performed if gram quantities of CTs were available. $^{1}$

The understanding of the modulations during rumen digestion and the ensiling process has made significant progress in the past, but we still lack a basic understanding of how $\mathrm{CT}$-protein interactions translate into improved livestock production, which is partly due to the difficulty of obtaining highly pure and wellcharacterized CTs. Several procedures have been developed for securing purified CTs, and most purifications commence with extraction from the plant material with an aqueous solvent mixture of common protic solvents (methanol or ethanol) or acetone/water mixtures. These initial extracts are often purified using either Sephadex LH-20 $0^{11-13}$ or Toyopearl HW-50F columns, ${ }^{14-16}$ although some studies also used sequential exposure to a combination of Sephadex LH-20, Toyopearl TSK HW-50F, Amberlite XAD7HP, or poly(styrene/divinylbenzene) (PS/DVB) polymer resins. ${ }^{14,16-19}$ Water or methanol/water mixtures are often used as a first eluent to remove carbohydrates and low molecular weight phenolics from the resins, after which the CTs are eluted with $70 \%$ acetone/water from Sephadex LH-20 columns. ${ }^{20}$ However, depending on the plant source, this aqueous acetone fraction may still contain $>50 \%$ of contaminants on a mass basis and is rarely suitable as a "CT" standard. For this reason, Grabber et al. ${ }^{21}$ stressed the importance of establishing the actual CT content in the standards used for colorimetric assays via either separate analysis such as thiolysis ${ }^{22}$ or $\mathrm{NMR}^{23}$ as CT content will otherwise be overestimated.

Received: July 27, 2017

Revised: $\quad$ August 14, 2017

Accepted: August 16, 2017

Published: August 16, 2017 


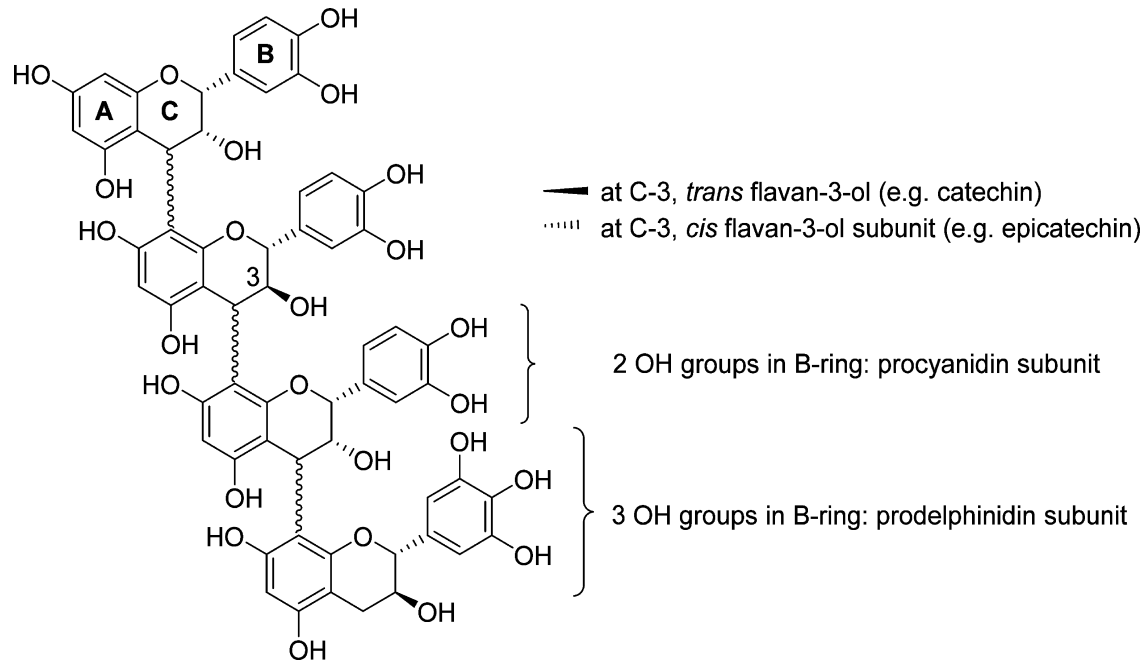

Figure 1. Example of a condensed tannin (syn. proanthocyanidin) structure.

Indeed, a variety of materials have been suggested as reference standards for colorimetric assays. These include CTs purified from the commercially available quebracho extracts or apples $^{14}$ or commercially available delphinidin and cyanidin chlorides. However, it has been shown that all of these polyphenols vary greatly in their UV-vis absorbance yields. ${ }^{14,24}$ Moreover, most plant materials typically contain mixtures of procyanidins (PC) and prodelphinidins (PD), which also generate different absorbance yields, and readings depend on the $\mathrm{PC} / \mathrm{PD}$ ratios of their CTs. ${ }^{25}$ Therefore, it is important that CT content be measured using a purified CT sample of known and high purity from the plant material undergoing analysis as the reference standard. ${ }^{21,24-27}$ However, it is a major undertaking to purify CTs and determine their purity as the removal of impurities can be challenging and time-consuming. Proteins, carbohydrates, and lipids are strong CT-binders. ${ }^{4,17,28}$ The novice researcher will find an array of different methods but little guidance on the advantages and disadvantages of various chromatographic resins, column conditions, or sample sizes that can be loaded to achieve high CT purities and yields. Moreover, few publications report the $\mathrm{CT}$ yields that can be expected from a particular purification setup or from a specific plant material. ${ }^{13}$

In this study, we first compared and contrasted two of the most widely used resins for the purification of CTs, Sephadex LH-20 and Toyopearl HW-50F, with the overall goal of selecting one resin for purification of gram quantities of CT samples. After selection of the preferred resin, we investigated different solvent elution schemes to purify CTs from plant sources with a wide range of composition ${ }^{29}$ to enable structure-activity relationship studies. ${ }^{6-10}$ The composition and purities in these fractions were analyzed through a combination of NMR spectroscopy and thiolytic degradation. This communication compiles the results of several studies, developed in two separate laboratories, in an effort to provide researchers with a choice of easy-to-use CT purification methods.

\section{MATERIALS AND METHODS}

Plant Samples. The tannin composition, collection, and processing of plant materials has been previously described. ${ }^{9,21,22,29-31}$ These include aerial parts of the sainfoin (Onobrychis viciifolia Scop; 'Cotswold Common') $)^{22}$ and NIAB sainfoin accessions (1123, 1127, $1165 \mathrm{r} 1){ }^{30}$ white clover (Trifolium repens L.) flowers, ${ }^{9}$ aerial parts of birdsfoot trefoil (Lotus corniculatus L.), big trefoil (L. pedunculatus Cav.), and crown vetch (Securigera varia (L.) Lassen), ${ }^{9,21}$ Tilia inflorescentia flowers (a mixture of Tilia cordata P. Mill., T. platyphyllos Scop., and T. vulgaris Hayne) were from Flos (Mokrsko, Poland), ${ }^{31}$ and two batches of pelleted leaf meal of sericea lespedeza (Lespedeza cuneata (Dum. Cours.) G. Don) were from Sims Brothers Seed Company (Union Springs, AL). Weeping willow (Salix babylonica L.) catkins were collected in Emmer Green (Reading, U.K.). Goat willow (S. caprea L.) leaves were collected from the University of Wisconsin Arboretum (Madison, WI). High tannin "Mediterranean" birdsfoot trefoil, aerial parts, was grown from combined seed sown from high tannin accessions (PI 235525, France; PI 246720, Spain; PI 249753, Greece; PI 260268, Ethiopia; PI 273937, Ethiopia; PI 273938, Ethiopia) that were provided by the National Genetic Resources Program as described. ${ }^{32}$ Black currant leaves (Ribes nigrum L.) were collected from Carandale Farm LLC (Oregon, WI).

Materials. Acetone (AR grade) and methanol (HPLC grade) were purchased from ThermoFisher Scientific Ltd. (Loughborough, U.K.) or Sigma (St. Louis, MO), deionized water was purified in an Option 3 water purifier (ELGA Process Water, Marlow, U.K.) or ultrapure water (Milli-Q Plus system, Millipore, Watford, UK and Billerica, MA), and dichloromethane was obtained from Sigma (St. Louis, MO). Sephadex LH-20 was obtained from GE Healthcare (Little Chalfont, U.K. and Marlborough, MA), and Toyopearl HW-50F from Hichrom Ltd. (Theale, Berks., U.K.).

Condensed Tannin Analysis. CT content (purity) and composition were determined by thiolytic degradation with benzylmercap$\tan ^{22,31}$ Where necessary, a combination of NMR (providing CT composition) $)^{23}$ and $\mathrm{HCl}$-butanol-acetone colorimetric assay (providing CT content/purity ${ }^{21}$ relative to previously analyzed reference standard CT samples of the same plant material) were used.

General Extraction Procedure for Crude Plant Extracts. The freeze-dried and cyclone-milled ( $\leq 1 \mathrm{~mm}$ ) (UDY Corporation, Fort Collins, CO) plant samples were extracted with acetone/water (7:3, $\mathrm{v} / \mathrm{v}$ ) using a magnetic stirrer for 30-40 $\mathrm{min}$ at room temperature, in some cases multiple times (i.e., 3 times), with solvent volume/sample weight ratios of 6 to 16 . The solutions were filtered under vacuum and concentrated on a rotary evaporator $\left(<35^{\circ} \mathrm{C}\right)$ to remove acetone. The resulting aqueous layer was extracted two or three times and phaseseparated in a separatory funnel with an equal volume of dichloromethane. The aqueous phase was concentrated on a rotary evaporator to remove any traces of dichloromethane and freeze-dried, and then these crude extracts were stored at $-20^{\circ} \mathrm{C}$.

CT Purification Methods. Four different protocols were evaluated for the generation of high purity CTs at the milligram to gram scale. All purified CT samples were stored at $-20{ }^{\circ} \mathrm{C}$.

Method 1: "Standard Column" Toyopearl HW-50F Chromatography. Four sainfoin accessions ( 25 g; 1123, 1127, 1165r1, Cotswold Common $)^{33}$ were extracted with acetone/water $(7: 3, \mathrm{v} / \mathrm{v} ; 200 \mathrm{~mL})$ as 
described above, yielding the crude plant extracts (yield: 15.6\%, 15.3\%, $22.0 \%, 15.8 \%$, respectively). Samples of the crude extracts ( $2 \mathrm{~g}$ each) were dissolved in ultrapure water $(20 \mathrm{~mL})$ and separated on a Toyopearl HW-50F column $(230 \times 30 \mathrm{~mm})$. The column was rinsed first with water $(3 \times 100 \mathrm{~mL}$; giving Toyopearl fractions T1-T3), then with methanol/water $(3 \times 100 \mathrm{~mL} ; 1: 1, \mathrm{v} / \mathrm{v}$, yielding T4-T6), and CTs were eluted with acetone/water $(7: 3, \mathrm{v} / \mathrm{v} ; 3 \times 100 \mathrm{~mL})$, providing fractions TF7-TF9, and finally with acetone to give fraction TF10 $(100 \mathrm{~mL})$. All fractions were concentrated on a rotary evaporator and freeze-dried.

Method 2: "Standard Column" Chromatography on Toyopearl HW-50F versus Sephadex LH-20. Prepurification: The Cotswold Common sainfoin accession $(25 \mathrm{~g})^{22}$ was extracted with acetone/ water $(7: 3, \mathrm{v} / \mathrm{v} ; 400 \mathrm{~mL})$ as described above (yield: $24.1 \%)$. A Sephadex LH-20 column $(120 \times 30 \mathrm{~mm}$ i.d. $)$ equilibrated with methanol/water $(1: 1, \mathrm{v} / \mathrm{v})$ was conditioned with water $(600 \mathrm{~mL})$ just before use. The crude extract $(6.0 \mathrm{~g})$ was dissolved in water $(40 \mathrm{~mL})$ and loaded onto the column. The column was washed with water (5 L) until there was a negative reaction to carbohydrates with the phenol test. ${ }^{34}$ Then a single, partially purified CT fraction was eluted with acetone/water $(7: 3, \mathrm{v} / \mathrm{v} ; 2 \mathrm{~L})$. Acetone was removed with a rotary evaporator, and the aqueous phase freeze-dried (yield: $477 \mathrm{mg}$ ). The extraction and purification were repeated to generate sufficient material by pooling both sets of acetone/water fractions for the subsequent column purification comparison.

Chromatography. Two aliquots of the partially purified, pooled CT mixture $(379.5 \mathrm{mg}$ each) were then dissolved in water $(10 \mathrm{~mL})$ and loaded onto either a Toyopearl HW-50F column or a Sephadex LH-20 column of identical sizes (185 mm length $\times 30 \mathrm{~mm}$ i.d.). Columns were rinsed with water $(100 \mathrm{~mL})$, and fractions were eluted with water $(3 \times 100 \mathrm{~mL}$; giving Toyopearl fractions T1-T3 or Sephadex fractions S1-S3), methanol/water $(3 \times 100 \mathrm{~mL} ; 1: 1, \mathrm{v} / \mathrm{v}$, yielding T4-T6 or S4-S6 fractions), acetone/water (100, 50, 50, $100 \mathrm{~mL}, 7: 3, \mathrm{v} / \mathrm{v}$, yielding T7, T8a, T8b, T9 or S7, S8a, S8b, S9 fractions), and acetone (100 mL; T10 or $\mathbf{S 1 0}$ fractions).

For Methods 3 and 4, the following fraction designations are used: For pre-elution washes, F0; for the 3:7, 1:1, and 7:3 (or 4:1) acetone/ water fractionation, F1, F2, and F3, respectively.

Method 3: "Wide Column" Sephadex LH-20 Chromatography. A slurry of Sephadex LH-20 (50 g) in water was poured into a glass column $(400 \times 65 \mathrm{~mm}$ i.d.) equipped with a sintered-glass frit, resulting in a resin bed of $70 \times 65 \mathrm{~mm}$ i.d. Plant samples $(50 \mathrm{~g})$ were extracted with acetone/water $(7: 3, \mathrm{v} / \mathrm{v} ; 500 \mathrm{~mL})$ by stirring at room temperature for $40 \mathrm{~min}$, filtering, and extracting in a separatory funnel with dichloromethane $(250 \mathrm{~mL})$. The upper, aqueous phase was concentrated on a rotary evaporator to remove trace volatile organic solvents and centrifuged to remove insoluble material. The aqueous phase containing ca. $10 \mathrm{~g}$ of crude plant extract was stored in a freezer overnight and thawed the next day, diluted with deionized water $(1 \mathrm{~L})$, and filtered, and then water $(1 \mathrm{~L})$ was added. This solution was transferred to a separatory funnel above the glass column. The CT solution was allowed to flow, slowly initially, along the inside of the column without disturbing the resin bed, and then rapidly once sufficient liquid was above the column, onto the Sephadex LH-20 resin (ca. $40 \mathrm{~mL} / \mathrm{min}$ ). Then $2 \mathrm{~L}$ of deionized water was added to the funnel and the column rinsed until the eluent was clear (flow rate: $40-50 \mathrm{~mL} / \mathrm{min})$. Acetone/water $(3: 7, \mathrm{v} / \mathrm{v}, 1 \mathrm{~L})$ was added to the separatory funnel, and the first $200 \mathrm{~mL}$ of eluent discarded. The CTs were collected at $15 \mathrm{~mL} / \mathrm{min}$ with the next $500 \mathrm{~mL}$ giving F1 (vanillin/ $\mathrm{HCl}$ was used to test for CTs in eluent). ${ }^{26} \mathbf{F} 2$ was similarly eluted with acetone/water $(1: 1, \mathrm{v} / \mathrm{v}, 1 \mathrm{~L})$, where the first $200 \mathrm{~mL}$ of eluent was discarded and CTs were collected at $25 \mathrm{~mL} / \mathrm{min}$ with the next $300 \mathrm{~mL}$. The column was reconditioned with water $(2 \mathrm{~L})$ at $25 \mathrm{~mL} / \mathrm{min}$. Columns could be reused approximately 10 times without losing separation efficiency as monitored by thiolysis of each fraction.

Method 4: "Batch Chromatography" with Sephadex LH-20. General Purification Protocol. The crude CT extract (4.5-19 g) obtained from the acetone/water $(7: 3 \mathrm{v} / \mathrm{v})$ extraction was dissolved in 1:1 methanol/water ( $30 \mathrm{~mL}$ of solvent per $\mathrm{g}$ of extract), and the resulting mixture was briefly stirred to dissolve the material.
Sephadex LH-20 (10 g per g of extract) was added in small portions, while stirring with a spatula, until the mixture reached the consistency of wet sand. The extract-laden resin was transferred to a coarse sintered-glass Buchner filter funnel $(600-1500 \mathrm{~mL})$ equipped with a filter paper. The resin was stirred with a mixture of methanol/water (1:1, v/v; $5 \mathrm{~mL} / \mathrm{g}$ Sephadex LH-20). The suspension was allowed to settle for $10 \mathrm{~min}$ and then vacuum filtered. This process of resin washing was repeated two additional times using methanol/water, and the filtrates were combined to provide the pre-elution fraction (F0). The resin was then washed in the same manner consecutively ( 3 times each with $5 \mathrm{~mL} / \mathrm{g}$ Sephadex LH-20 per washing) with solutions of acetone/water of decreasing polarity $(3: 7 ; 1: 1 ; 7: 3)$ to give fractions F1-F3, respectively. Fractions were concentrated on a rotary evaporator $\left(<35{ }^{\circ} \mathrm{C}\right)$ to remove the volatile organic solvent, and the resulting aqueous phases were freeze-dried. The purity of the fractions was qualitatively assessed by NMR spectroscopy, ${ }^{23}$ and this analysis led to the selection of the higher CT content fractions for thiolytic degradation analysis or the lower CT content fractions for a second purification, prefixed with the label $\mathbf{P 2}$, leading to production of fractions P2F0, P2F1, P2F2, and P2F3.

Specific Example. Crude extract (12 g) from black currant leaves $(50 \mathrm{~g})$ was dissolved in 1:1 methanol/water $(300 \mathrm{~mL})$, and the resulting mixture was briefly stirred to dissolve the material. Sephadex LH-20 (120 g) was added in small portions, stirring with a spatula. After transferring the CT-adsorbed resin to a $1500 \mathrm{~mL}$ coarse sinteredglass Buchner filter funnel containing a filter paper, the resin was processed as described above in the general purification protocol using methanol/water $(1: 1 \mathrm{v} / \mathrm{v} ; 3 \times 650 \mathrm{~mL})$ and acetone/water $(3: 7 ; 1: 1$; and $7: 3 \mathrm{v} / \mathrm{v} ; 3 \times 650 \mathrm{~mL}$ each) to afford, after freeze-drying, F1 (336 mg), F2 (2000 mg), and F3 (692 mg, 98\% CT). Repurification of the combined F2 and F3 fractions produced P2F0 (532 mg), P2F1 (186 mg), P2F2 (913 mg, >99\% CT), and P2F3 (440 mg, >99\% CT). A parallel, smaller scale purification of crude black currant leaf extract $(4.5 \mathrm{~g})$, which did not require a second purification, produced F0 (1670 mg), F1 (212 mg), F2 (508 mg, >99\% CT), and F3 (643 mg, 96\% CT).

NMR Spectroscopy. ${ }^{1} \mathrm{H}$ NMR, ${ }^{13} \mathrm{C}$ NMR, and ${ }^{1} \mathrm{H}-{ }^{13} \mathrm{C}$ HSQC NMR spectra were recorded on an Avance $360\left({ }^{1} \mathrm{H} 360.13 \mathrm{MHz},{ }^{13} \mathrm{C}\right.$ $90.55 \mathrm{MHz}$ ) instrument equipped with XWINNMR software (Bruker Corporation, Billerica, MA). Spectra were recorded in $\mathrm{D}_{2} \mathrm{O}$ /acetone- $d_{6}$ $(4: 1)$ and were referenced to the residual signals of acetone- $d_{6}(2.04$ ppm for ${ }^{1} \mathrm{H}$ and 29.8 ppm for ${ }^{13} \mathrm{C}$ spectra). For ${ }^{1} \mathrm{H}-{ }^{13} \mathrm{C}$ HSQC experiments, spectra were obtained using 128 scans (acquisition time $18 \mathrm{~h}$ $30 \mathrm{~min}$ each) with the standard Bruker pulse program (invietgpsi) with the following parameters: Acquisition: TD 1584 (F2), 768 (F1); SW 11.0 ppm (F2), 160 ppm (F1); O1 $1800.65 \mathrm{~Hz}$; O2 7244.38 Hz; D1 = $1.00 \mathrm{~s} ; \mathrm{CNST} 2=145$. Acquisition time: F2 channel, $200 \mathrm{~ms}$, F1 channel $2.65 \mathrm{~ms}$. Processing: SI = $1024(\mathrm{~F} 2, \mathrm{~F} 1)$, WDW = QSINE, $\mathrm{LB}=-0.76 \mathrm{~Hz}(\mathrm{~F} 2), 0.30 \mathrm{~Hz}(\mathrm{~F} 1) ; \mathrm{PH} \bmod =$ pk; Baseline correction $\mathrm{ABSG}=5(\mathrm{~F} 2, \mathrm{~F} 1), \mathrm{BCFW}=1.00 \overline{\mathrm{ppm}}, \mathrm{BC} \bmod =$ quad $(\mathrm{F} 2)$, no $(\mathrm{F} 1)$; Linear prediction $=$ no $(\mathrm{F} 2), \mathrm{LPfr}(\mathrm{F} 1)$. Sample sizes used for these spectra ranged from 10 to $15 \mathrm{mg}$, providing NMR sample solutions with concentrations of $20-30 \mathrm{mg} / \mathrm{mL}$.

\section{RESULTS AND DISCUSSION}

The purification of CTs poses numerous challenges. First, CTs are most effectively extracted with aqueous acetone but these extracts also contain sugars, phenolic acids, cinnamic acids, flavonoids, amino compounds, proteins, nucleic acids, and lipids. $^{35-39}$ Second, CTs occur in homo- and heterogeneous mixtures ${ }^{31}$ that can include a wide range of molecular weights, $\mathrm{PC} / \mathrm{PD}$ and cis/trans ratios, plus a mixture of A- or B-type interflavan linkages. Finally, large polymers can be particularly difficult to isolate as they tend to adsorb strongly to plant materials ${ }^{40}$ and column packings. ${ }^{41}$ Toyopearl HW-50F and Sephadex LH-20 are the most widely used resins for their purification, ${ }^{11-17,40}$ but the purities of the eluted CTs are variable and are often not reported. Thus, we began our studies 
Table 1. Yields and Composition of Condensed Tannin (CT) Fractions Purified from Crude Sainfoin Extracts on a Standard Toyopearl HW-50F Column (Method 1) ${ }^{a}$

\begin{tabular}{|c|c|c|c|c|c|c|}
\hline sainfoin accession & fraction no. & fraction yield $(\mathrm{mg})^{b}$ & $\mathrm{CT}$ content $(\mathrm{g} / 100 \mathrm{~g} \text { fraction })^{c d}$ & $\mathrm{mDP}^{c d}$ & $\mathrm{PC} / \mathrm{PD}^{c d}$ & cis/trans ${ }^{c d}$ \\
\hline \multirow[t]{4}{*}{ NIAB 1123 (CPI 63763) } & TF7 & $36(18)$ & $12.6(3.0)$ & $5.2(0.5)$ & $39.3 / 60.7(4.4)$ & $79.3 / 20.7(6.1)$ \\
\hline & TF8 & $91(25)$ & $54.6(4.0)$ & $7.7(0.1)$ & $24.1 / 75.9(0.1)$ & $74.8 / 25.2(0.9)$ \\
\hline & TF9 & $19(2)$ & $43.8(1.1)$ & $9.2(0.1)$ & $20.7 / 79.3(0.2)$ & $73.0 / 27.0(1.8)$ \\
\hline & TF10 & $7(4)$ & $49.4(1.5)$ & $22.2(1.5)$ & $12.5 / 87.5(0.1)$ & $75.8 / 24.2(0.9)$ \\
\hline \multirow[t]{4}{*}{ NIAB 1127 (CPI 63767) } & TF7 & $11(7)$ & $3.30(0.01)$ & $6.4(1.2)$ & $100.0 / 0.0(0.0)$ & $63.3 / 36.7(7.0)$ \\
\hline & TF8 & $93(10)$ & $50.9(1.0)$ & $6.6(0.3)$ & 28.3/71.7 (1.6) & $73.4 / 26.6(1.6)$ \\
\hline & TF9 & $25(6)$ & $43.4(1.1)$ & $25.5(2.6)$ & $11.0 / 89.0(0.1)$ & $77.6 / 22.4(0.4)$ \\
\hline & TF10 & $7(0)$ & $59.2(3.6)$ & $95.0(8.8)$ & $11.5 / 88.5(0.1)$ & $81.6 / 18.4(0.4)$ \\
\hline \multirow[t]{4}{*}{ NIAB 1165r1 (Rees "A") } & TF7 & $39(20)$ & $3.64(0.55)$ & $1.9(0.2)$ & $68.9 / 31.1(0.3)$ & $60.4 / 39.6(0.1)$ \\
\hline & TF8 & $221(52)$ & $60.1(9.8)$ & $8.6(0.5)$ & $39.6 / 60.4(0.3)$ & $76.9 / 23.1(0.5)$ \\
\hline & TF9 & $54(30)$ & $56.0(0.7)$ & $18.2(0.1)$ & $19.1 / 80.9(0.3)$ & $78.0 / 22.0(3.7)$ \\
\hline & TF10 & $11(8)$ & $46.0(1.0)$ & $22.7(0.2)$ & $17.5 / 82.5(0.3)$ & $77.0 / 23.0(1.5)$ \\
\hline \multirow[t]{4}{*}{ Cotswold Common } & TF7 & $53(13)$ & $37.0(2.4)$ & $4.5(0.1)$ & $55.3 / 44.7(0.8)$ & $78.6 / 21.4(1.3)$ \\
\hline & TF8 & $147(20)$ & $54.3(0.3)$ & $9.5(0.5)$ & $40.4 / 59.6(1.6)$ & $76.0 / 24.0(1.0)$ \\
\hline & TF9 & $35(5)$ & $43.6(3.2)$ & $27.6(8.5)$ & $22.4 / 77.6(0.9)$ & $77.7 / 22.3(2.4)$ \\
\hline & TF10 & $21(8)$ & $44.6(0.1)$ & $60.9(8.7)$ & $22.9 / 77.1(0.3)$ & $79.6 / 20.4(1.1)$ \\
\hline
\end{tabular}

${ }^{a}$ Abbreviations used: \% PD: molar percentage of procyanidins/prodelphinidins; cis/trans: molar percentages of cis/trans flavan-3-ols. ${ }^{b}{ }_{n}=2$ (chromatographic runs). ${ }^{c} n=3$ (analytical replicates by thiolysis). ${ }^{d}$ Fractions were analyzed by thiolysis with benzylmercaptan (standard deviations in parentheses).

Table 2. Yield and Composition of Condensed Tannin (CT) Fractions Purified from a Crude Sainfoin ('Cotswold Common' var.) Extract on Standard Columns of Either Sephadex LH-20 or Toyopearl HW-50F (Method 2) ${ }^{a}$

\begin{tabular}{|c|c|c|c|c|c|c|}
\hline columns and eluents & fraction & fraction yield $(\mathrm{mg})$ & $\mathrm{CT}$ content $(\mathrm{g} / 100 \mathrm{~g} \text { fraction })^{c}$ & $\mathrm{mDP}^{c}$ & $\mathrm{PC} / \mathrm{PD}^{c}$ & cis/trans ${ }^{c}$ \\
\hline \multicolumn{7}{|l|}{ Sephadex LH-20 } \\
\hline \multirow{3}{*}{ water } & S1 & 40.4 & $2.8(0.1)$ & $12.4(0.3)$ & $77.5 / 22.5(1.5)$ & $96.7 / 3.3(0.4)$ \\
\hline & S2 & 4.8 & $1.8(0.1)$ & $4.6(0.2)$ & $80.3 / 19.7(1.9)$ & $94.1 / 5.9(1.3)$ \\
\hline & S3 & 2.6 & $1.2(0.2)$ & $4.6(0.3)$ & $81.6 / 18.4(3.2)$ & $95.5 / 4.5(0.5)$ \\
\hline \multirow[t]{3}{*}{ methanol/water $(1: 1, \mathrm{v} / \mathrm{v})$} & S4 & 4.8 & $2.0(0.1)$ & $5.7(0.3)$ & $79.9 / 20.1(0.1)$ & $95.6 / 4.4(0.8)$ \\
\hline & S5 & 13.6 & $4.5(0.4)$ & $6.1(0.4)$ & $74.1 / 25.9(3.4)$ & $94.7 / 5.3(0.1)$ \\
\hline & S6 & 10.9 & $2.2(0.3)$ & $7.4(1.1)$ & $78.8 / 21.2(3.1)$ & $94.3 / 5.7(1.4)$ \\
\hline \multirow[t]{4}{*}{ acetone/water $(7: 3, \mathrm{v} / \mathrm{v})$} & S7 & 118.7 & $84.5(7.7)$ & $10.3(0.1)$ & $46.5 / 53.5(0.2)$ & $85.5 / 14.5(0.3)$ \\
\hline & S8a & 105.5 & $101.8(2.0)$ & $7.4(0.1)$ & $49.8 / 50.2(0.2)$ & $79.4 / 20.6(0.1)$ \\
\hline & S8b & 32.6 & $88.1(1.1)$ & $8.0(0.1)$ & $42.3 / 57.7(0.4)$ & $79.4 / 20.6(0.1)$ \\
\hline & S9 & 18.0 & $80.4(0.9)$ & $10.0(0.5)$ & $35.4 / 64.6(0.8)$ & $81.5 / 18.5(0.2)$ \\
\hline acetone & S10 & 3.2 & $68.1(5.9)$ & $14.9(0.7)$ & $33.0 / 67.0(0.4)$ & $82.8 / 17.2(0.1)$ \\
\hline recovery & & 355.1 & & & & \\
\hline \multicolumn{7}{|l|}{ Toyopearl HW-50F } \\
\hline \multirow{3}{*}{ water } & $\mathrm{T} 1$ & 28.0 & $15.2(0.3)$ & $38.2(2.7)$ & $31.5 / 68.5(0.1)$ & $91.5 / 8.5(0.3)$ \\
\hline & $\mathrm{T} 2$ & 4.5 & $0.4(0.1)$ & $-b$ & $100.0 / 0.0(0.0)$ & $100.0 / 0.0(0.0)$ \\
\hline & $\mathrm{T} 3$ & 1.5 & nd & & & \\
\hline \multirow[t]{3}{*}{ methanol/water $(1: 1, \mathrm{v} / \mathrm{v})$} & $\mathrm{T} 4$ & 2.5 & nd & & & \\
\hline & T5 & 4.9 & $4.2(0.4)$ & $4.9(0.4)$ & $89.1 / 10.9(4.5)$ & $85.4 / 14.6(2.0)$ \\
\hline & $\mathrm{T} 6$ & 6.1 & $1.5(0.1)$ & $9.5(2.1)$ & $100.0 / 0.0(0.0)$ & $93.5 / 6.5(0.1)$ \\
\hline \multirow[t]{4}{*}{ acetone/water $(7: 3, \mathrm{v} / \mathrm{v})$} & $\mathrm{T} 7$ & 80.0 & $85.7(4.0)$ & $8.0(0.1)$ & $56.5 / 43.5(0.3)$ & $84.5 / 15.5(0.1)$ \\
\hline & T8a & 83.9 & $122.2(17.1)$ & $9.4(0.4)$ & $40.4 / 59.6(0.1)$ & $81.3 / 18.7(0.2)$ \\
\hline & $\mathrm{T} 8 \mathrm{~b}$ & 16.2 & $90.5(8.3)$ & $23.4(1.0)$ & $15.2 / 84.8(0.1)$ & $85.6 / 14.4(0.1)$ \\
\hline & T9 & 37.5 & $73.8(13.7)$ & $53.7(3.7)$ & $10.8 / 89.2(0.2)$ & $88.1 / 11.9(0.5)$ \\
\hline acetone & $\mathrm{T} 10$ & 3.0 & $73.1(0.6)$ & $45.8(1.4)$ & $14.0 / 86.0(0.1)$ & $88.5 / 11.5(0.1)$ \\
\hline recovery & & 268.1 & & & & \\
\hline
\end{tabular}

${ }^{a}$ Abbreviations used: mDP: mean degree of polymerization; PC/PD: molar percentages of procyanidins/prodelphinidins; cis/trans: molar percentages of cis/trans flavan-3-ols. ${ }^{b}$ nd: $\mathrm{mDP}$ value could not be calculated as peaks of terminal units were too small to be detected. ${ }^{c}$ Fractions were analyzed by thiolysis with benzylmercaptan ( $n=3$; SD in parentheses).

to directly compare these resins in a side-by-side purification. We first tested the hypothesis that Toyopearl HW-50F enables better separation and purification of CTs than Sephadex LH-20.

Method 1: Toyopearl HW-50F Chromatography for CT Separations. Table 1 shows the CT content and composition of fractions eluted from a Toyopearl HW-50F column using extracts from four sainfoin accessions. The $70 \%$ acetone fractions (TF7-TF9) yielded masses of 11-53, 91-221, and 19-54 mg, respectively, with pure acetone (TF10) eluting only 7-21 mg. The \% CT content in these fractions varied considerably and increased from TF7 (3-37\% CT) to TF8 (51-60\% CT), but decreased slightly in TF9 (43-56\% CT) 
and TF10 (45-59\% CT). It can be clearly seen (Table 1) that aqueous acetone and acetone eluted CTs according to polymer size with $\mathrm{mDP}$ values of TF7-TF10 fractions of 2-6, $7-10,9-28$, and $22-95$, respectively. The latter fraction is of particular interest, as large molecular weight CTs are difficult to purify and are often obtained only in milligram quantities. Sainfoin CTs consist of complex mixtures ${ }^{33}$ and Toyopearl HW-50F achieved some separation into CTs rich in PC and PD subunits. Molar percentages of PD increased from TF7 (0-60\%), TF8 (60-76\%), TF9 (78-89\%), to TF10 (77-89\%). The most likely explanation for this separation stems from our observations that many plants tend to synthesize PC as smaller polymers and PD as larger polymers, although exceptions exist. ${ }^{42}$ An alternative explanation for the decreasing $\mathrm{PC} / \mathrm{PD}$ ratios and increasing $\mathrm{mDP}$ with higher acetone content in the eluent could be due to hydrogen bonding. Smaller CTs containing a preponderance of PC subunits would likely desorb faster from the hydrophilic surface of Toyopearl HW-50F whereas CTs with higher PD content/molecular weight require the disruption of a larger number of hydrogen bonds with the resin before they can elute. Molar percentages of trans-flavan-3ols varied most in the first fraction, i.e., from 21 to $40 \%$ (TF7), and much less in subsequent fractions $(23-27 \%$ in TF8, $22-27 \%$ in TF9, and $18-24 \%$ in TF10). It can be concluded that fractionation on a Toyopearl HW-50F column achieved good CT separations based on molecular weights and PC/PD ratios, but that other approaches were needed to increase the quantity and purity of the isolated CTs. Next, we evaluated standard length columns packed with Sephadex LH-20 and Toyopearl HW-50F and stepwise solvent elutions in a side-toside comparison, after an initial prepurification step.

Method 2: Sephadex LH-20 versus Toyopearl HW-50F Chromatography. Partially purified CTs, rather than crude acetone/water (7:3) plant extracts, were required before direct comparison of the Sephadex LH-20 and Toyopearl HW-50F columns could be conducted. Unless a prior purification of the crude plant extract was performed on Sephadex LH-20, the subsequent Toyopearl HW-50F column purification suffered from slow flow rates and poor sample recoveries. Identical quantities of this partially purified CT sample were then applied to equally sized Sephadex LH-20 and Toyopearl HW-50F columns. The mass recoveries from the Sephadex LH-20 and Toyopearl HW-50F columns were $94 \%$ and $71 \%$, respectively, of the applied sample (Table 2). Similar percentages of the extract, based on the recovered material, were obtained from the Sephadex LH-20 and Toyopearl HW-50F columns with each of the eluents: water eluted $14 \%$ and $13 \%$, aqueous methanol eluted $8 \%$ and $5 \%$, aqueous acetone eluted $77 \%$ and $81 \%$, respectively, and acetone eluted just $1 \%$ from either column (Table 2). These solvents also eluted fractions with comparable CT content from both columns. Water and aqueous methanol eluted fractions with just $1-5 \%$ CT from the Sephadex LH-20 and $0-15 \%$ CT from the Toyopearl HW-50F column. We note that the first water fraction from both columns contained an unexpected group of CTs with $\mathrm{mDP}$ values of 12 and 38. It is possible that these CTs were either glycosylated or may have formed water-soluble complexes with other materials and then simply been washed off the column as complexes that did not extensively interact with the resin but these were not investigated further.

The first three aqueous acetone fractions $\mathbf{7}, \mathbf{8 a}$, and $\mathbf{8 b}$ had the highest CT contents, i.e. $85-100 \%$. However, acetone on its own also eluted CTs but of lower purities, $68 \%$ and $73 \%$ CT for S10 and T10, respectively. Our results indicate that acetone also elutes lipids from Sephadex LH-20, which suggests that CTs, just like gallotannins, are strong phospholipid binders. ${ }^{43}$ NMR studies from the USDA laboratory revealed that lipid materials elute from Sephadex LH-20 late in these elution schemes as evidenced by carbon-carbon double bond $\mathrm{C}-\mathrm{H}$ cross peaks ${ }^{44}$ present in the ${ }^{1} \mathrm{H}-{ }^{13} \mathrm{C}$ HSQC NMR spectra of these fractions. CTs eluted from Sephadex LH-20 with decreasing $\mathrm{PC} / \mathrm{PD}$ ratios, i.e. from $78 / 22$ to $33 / 67$, but $\mathrm{mDP}$ values also increased slightly in the acetone-containing fractions. In contrast, fractions from the Toyopearl HW-50F column generated fractions with distinctly different $\mathrm{PC} / \mathrm{PD}$ ratios that decreased from $100 / 0$ to $14 / 86$ and $\mathrm{mDP}$ values that increased from 5 to 46. In addition, CTs also separated according to PCs or PDs on the Toyopearl HW-50F column; for example, the T6 and T8a fractions had similar $\mathrm{mDP}$ values $(\sim 9.5)$ but very different PC/PD ratios (100/0 and 40/60).

Toyopearl HW-50F also yielded CTs with different compositions in the water and aqueous methanol fractions: the CTs in T1 consisted of $69 \% \mathrm{PD}$ with a high $\mathrm{mDP}$ of 38 , but the CTs in T2 had only epicatechin (EC) subunits and presumably a very high $\mathrm{mDP}$ as no terminal units could be detected. In contrast, the Sephadex LH-20 water and aqueous methanol fractions (S1-S6) had relatively similar PC/PD ratios and $\mathrm{mDP}$ values.

Aqueous acetone and acetone (T7-T10) eluted CTs from Toyopearl-HW-50F with mDP-values of $8-54$, but the corresponding Sephadex LH-20 S7-S10 fractions had $\mathrm{mDP}$ values of 7-15. Flavan-3-ol subunit composition of CTs from the Toyopearl T2 and T5-T10 fractions had decreasing molar percentages of EC (100-13\%) and increasing epigallocatechin (EGC) percentages (10-78\%). The T2 fraction consisted of PC homopolymers that contained only EC subunits, the T6 fraction had both catechin (C) and EC subunits, whereas the water (T1) and acetone (T7-T10) fractions contained all four flavan-3-ol subunits. In comparison, the CTs in the Sephadex LH-20 water and methanol/water fractions $(\mathbf{S 1 - S 6 )}$ had EC and EGC as extension units and EC and $\mathrm{C}$ as terminal units. The acetone fractions (S7-S10) contained all four flavan-3-ols as terminal and extension units.

This comparison revealed that several highly pure CT fractions could be eluted from both columns provided that the crude plant extract was first partially purified over a Sephadex LH-20 column. Toyopearl HW-50F proved to be superior to Sephadex LH-20 in separating complex CT mixtures according to their $\mathrm{mDP}$ and $\mathrm{PC} / \mathrm{PD}$ ratios. However, separations took ca. $5 \mathrm{~h}$ in order to obtain between 3 and $120 \mathrm{mg}$ of CTs and, therefore, alternative approaches were needed to obtain larger quantities of CTs.

Methanol/water (1:1) is often used as the first eluent to remove carbohydrates and low molecular weight phenolics, and CTs are then eluted with $70 \%$ acetone/water. ${ }^{20}$ However, depending on the plant source, this aqueous acetone fraction may still contain considerable quantities of contaminants. On the basis of these results, we chose Sephadex LH-20 and our two laboratories worked separately with this resin to find a suitable method to deliver gram quantities of CTs of high purity.

Method 3: Wide Column Sephadex LH-20 Chromatography. Preliminary experiments showed that most contaminants in crude plant extracts could be removed by elution with water or methanol/water mixtures (1:9 or 3:7) using conventional columns (ca. $30 \mathrm{~mm}$ i.d.), but slow flow rates required $>8 \mathrm{~h}$ for separations. Therefore, we experimented next with 
Table 3. Fractionations of Crude Extracts from Seven Plant Species on a Short, Wide Sephadex LH-20 Column (Method 3) ${ }^{a}$

\begin{tabular}{|c|c|c|c|c|c|c|c|}
\hline plant species & $\begin{array}{l}\text { fraction, } \mathrm{F} \\
\text { (no. of runs) }\end{array}$ & $\begin{array}{l}\text { crude extract applied } \\
\text { to column }(\mathrm{g})\end{array}$ & fraction yield $(\mathrm{g})$ & $\begin{array}{c}\text { CT content } \\
(\mathrm{g} / 100 \mathrm{~g} \text { fraction })^{b}\end{array}$ & $\mathrm{mDP}^{b}$ & $\mathrm{PC} / \mathrm{PD}^{b}$ & cis/trans ${ }^{b}$ \\
\hline \multirow[t]{3}{*}{ birdsfoot trefoil } & F1 $(n=5)$ & 10 & 0.400 & $19.9(2.2)$ & $3.8(0.5)$ & $83.2 / 16.8(0.7)$ & $76.8 / 23.2(2.2)$ \\
\hline & $\mathrm{F} 2(n=4)$ & & $\sim 0.800$ & $77.7(5.2)$ & $12.7(2.0)$ & $67.0 / 33.0(2.5)$ & $91.0 / 9.0(1.0)$ \\
\hline & $\mathrm{F} 3(n=3)^{b}$ & & & $7.7(3.6)$ & $30.2(3.4)$ & $73.8 / 26.2(8.4)$ & $95.5 / 4.5(1.4)$ \\
\hline \multirow[t]{2}{*}{ big trefoil } & F1 $(n=4)$ & 10 & $\sim 0.800$ & $53.9(8.6)$ & $5.4(0.4)$ & $35.3 / 64.7(2.1)$ & $67.3 / 32.7(2.7)$ \\
\hline & $\mathrm{F} 2(n=4)$ & & $\sim 1.200$ & $104.2(8.1)$ & $17.8(1.1)$ & $24.9 / 75.1(0.5)$ & $84.4 / 15.6(0.2)$ \\
\hline \multirow[t]{3}{*}{ sericea lespedeza } & $\mathrm{F} 1(n=1)$ & 8.5 & 0.282 & 42.1 & 4.9 & $7.6 / 92.4$ & $65.3 / 34.7$ \\
\hline & $\mathrm{F} 2(n=1)$ & & 0.321 & 82.6 & 11.3 & $7.7 / 92.3$ & $75.2 / 24.8$ \\
\hline & $\mathrm{F} 3(n=1)^{c}$ & & 0.920 & 69.7 & 25.0 & $5.6 / 94.4$ & $80.8 / 19.2$ \\
\hline \multirow[t]{3}{*}{ Crownvetch } & $\mathrm{F} 1(n=5)$ & 13.7 & $0.276(0.093)$ & $23.2(11.8)$ & $11.7(1.5)$ & $25.2 / 74.8(4.4)$ & $86.7 / 13.3(1.4)$ \\
\hline & $\mathrm{F} 2(n=5)$ & & $0.174(0.074)$ & $63.5(11.3)$ & $13.6(1.3)$ & $26.3 / 73.7(0.7)$ & $88.1 / 11.9(0.4)$ \\
\hline & $\mathrm{F} 3(n=1)^{b}$ & & 0.004 & 43.0 & 20.3 & $25.7 / 74.3$ & $89.3 / 10.7$ \\
\hline \multirow[t]{2}{*}{ Tilia sp } & $\mathrm{F} 1(n=9)$ & 10 & $0.640(0.113)$ & $63.1(3.2)$ & $3.0(0.2)$ & $95.6 / 4.4(1.1)$ & $90.7 / 9.3(0.3)$ \\
\hline & $\mathrm{F} 2(n=9)^{b}$ & & $0.807(0.113)$ & $95.0(2.8)$ & $8.1(0.4)$ & $96.8 / 3.2(1.1)$ & $95.9 / 4.1(0.3)$ \\
\hline \multirow[t]{3}{*}{ weeping willow } & $\mathrm{F} 1(n=2)$ & nd & $0.146(0.033)$ & $32.7(10.6)$ & $2.9(0.1)$ & $74.7 / 25.3(0.9)$ & $56.4 / 43.6(1.3)$ \\
\hline & $\mathrm{F} 2(n=2)$ & & $0.222(0.070)$ & $79.2(25.7)$ & $8.4(0.1)$ & $68.5 / 31.5(2.1)$ & $63.0 / 37.0(7.5)$ \\
\hline & $\mathrm{F} 3(n=1)^{b}$ & & 0.023 & 52.1 & 13.6 & $58.2 / 41.8$ & $68.8 / 31.2$ \\
\hline \multirow{3}{*}{$\begin{array}{l}\text { sainfoin (Cotswold } \\
\text { Common var.) }\end{array}$} & $\mathrm{F} 1(n=2)$ & nd & $0.177(0.075)$ & $34.0(4.6)$ & $2.9(0.2)$ & $30.8 / 69.2(3.8)$ & $66.3 / 33.7(0.6)$ \\
\hline & $\mathrm{F} 2(n=2)$ & & $0.193(0.071)$ & $104.0(13.5)$ & $9.5(1.2)$ & $35.3 / 64.7(0.2)$ & $80.4 / 19.6(1.8)$ \\
\hline & $\mathrm{F} 3(n=1)^{b}$ & & 0.035 & 88.8 & 25.4 & $31.2 / 68.8$ & $84.3 / 15.7$ \\
\hline
\end{tabular}

${ }^{a}$ Abbreviations used: $\mathrm{mDP}$ : mean degree of polymerization; PC/PD: molar percentages of procyanidins/prodelphinidins; cis/trans: molar percentages of cis/trans flavan-3-ols; nd: not determined as the crude extract was rotary evaporated and the resulting aqueous phase was directly applied to the column. Note: the birdsfoot trefoil, big trefoil, and sericea lespedeza extracts were also subjected to Method 4 purification (Table 4). Condensed tannins (CT) in fractions were analyzed by thiolysis with benzylmercaptan (SD in parentheses). Fraction 1 (F1) was obtained by elution with acetone/water $(3: 7, \mathrm{v} / \mathrm{v})$, fraction 2 (F2) with acetone/water (1:1, v/v), and fraction 3 (F3) with acetone/water (7:3 or 8:2, v/v). ${ }^{b}$ Acetone/ water $(8: 2, \mathrm{v} / \mathrm{v}) .{ }^{c}$ Acetone/water $(7: 3, \mathrm{v} / \mathrm{v})$.

column dimensions that are typically used in flash column chromatography ${ }^{45}$ and found that a shorter, but wider Sephadex LH-20 column $(70 \times 65 \mathrm{~mm}$ i.d. $)$ enabled faster elution times. This approach expedited cleanup of 8-14 g quantities of crude extracts. After applying the crude extracts in water, this column was then rinsed with copious quantities of water (ca. $2 \mathrm{~L}$ ) and CTs were eluted with acetone/water $(3: 7, v / v)$ in $\mathbf{F} \mathbf{1}$ and with acetone/water $(1: 1, \mathrm{v} / \mathrm{v})$ in $\mathbf{F} 2$ within 4 to $5 \mathrm{~h}$. As an example, this fast chromatography of crude birdsfoot trefoil and big trefoil extracts yielded $400 \mathrm{mg}$ and $800 \mathrm{mg}$ in F1 and $800 \mathrm{mg}$ and $1200 \mathrm{mg}$ in $\mathbf{F} 2$, respectively, in a single run (Table 3). Crude extracts from other plants yielded F1 of $146-640 \mathrm{mg}$ and F2 of 174-321 mg. Elution with acetone/water (F3; 8:2, $\mathrm{v} / \mathrm{v}$ ) tended to yield just a few milligrams with most samples (4-35 mg), but the sericea lespedeza extract, having particularly high molecular weight prodelphinidins, ${ }^{46}$ gave $92 \mathrm{mg}$. Repeat fractionations on the same column gave coefficients of variation for mass recoveries in F1 and F2, respectively, for crown vetch $(n=5)$ of $34 \%$ and $44 \%$; for weeping willow $(n=2)$ of $23 \%$ and $31 \%$; for sainfoin of $42 \%$ and $37 \%$ and for Tilia sp. $(n=9)$ of $18 \%$ and $14 \%$ (the latter was an $8: 2$ acetone/water fraction).

Table 3 presents the CT contents and compositions from wide column separations of seven crude plant extracts obtained by five individual researchers. Purities of these CT samples ranged from 20 to $63 \%$ CT (F1), from 64 to $100 \%$ CT (F2), and from 8 to $89 \% \mathrm{CT}(\mathrm{F} 3)$. The $\mathrm{mDP}$ value ranges increased during elution; for F1 (3-12), F2 (8-18), and F3 (14-30). Thus, CTs can be quickly purified to a high degree directly from $10 \mathrm{~g}$ quantities of crude plant extracts and with moderate resolution into CT fractions of low and intermediate $\mathrm{mDPs}$ yielding up to $1.2 \mathrm{~g}$ of CTs. Use of the shorter, wider column enabled higher flow rates, minimizing on-column diffusion, thus increasing separation efficacy and recovery. This purification technique is comparable to flash chromatography that was first described by Still et al., ${ }^{45}$ wherein the authors reported that separation efficacy and recovery benefitted from a high eluent flow rate as it minimized on-column diffusion. An alternative explanation for how CTs may be fractionated during stepwise elution was proposed by Putman and Butler, ${ }^{41}$ who pointed out that a sudden change in solvent composition coupled to fast flow rates may give rise to conformational change or aggregation of CTs and lead to desorption from $\mathrm{C}_{18}-$ HPLC column surfaces. The present and other studies ${ }^{13}$ demonstrated that CTs with mDP values of 900-34200 Da can be separated on Sephadex LH-20 when using different solvents (Table 3), which suggests that chromatographic separation of CTs is based on both adsorption and molecular size. ${ }^{47}$

Method 4: Batch Chromatography on Sephadex LH-20. We also describe an alternative elution scheme using a batch chromatography approach to obtain gram quantities of highly pure CTs. This batch chromatography method uses Sephadex LH-20 and an elution scheme of (1:1) methanol/ water (F0), followed by 3:7 (F1), 1:1 (F2), and finally 7:3 (F3) acetone/water mixtures. Here, the crude extracts were adsorbed onto the resin, and the resin washed successively, and in portions, with each eluent over $30 \mathrm{~min}$. The wash solutions were removed using vacuum filtration. Total separation time was $2.5 \mathrm{~h}$.

To evaluate this method versus Methods 2 and 3, replicate purifications $(n=2)$ of crude sainfoin extract ( 2 g each) were performed. The resulting fractions were evaluated for CT composition and purity. The sainfoin fraction (F1-F3) purity $(20-96 \%)$ and the $\mathrm{mDP}(7-22)$ increased as the proportion of acetone in the eluent increased. These fractions provided similar molar \% PD (86-88) as the molar \% trans-flavan-3-ols decreased slightly (20-14). Similar trends in $\mathrm{mDP}, \% \mathrm{PD}$, and 
Table 4. Condensed Tannin (CT) Composition from Thiolysis Analysis of Replicate Fractionations $(n=1-3)$ of Plant Materials Purified Once by Batch Sephadex LH-20 Chromatography (Method 4) ${ }^{a}$

\begin{tabular}{|c|c|c|c|c|c|c|c|c|}
\hline & plant species & $\begin{array}{l}\text { fraction, } \mathrm{F} \\
\text { (no. of runs) }\end{array}$ & $\begin{array}{l}\text { crude extract applied to } \\
\text { column (g) }\end{array}$ & fraction yield $(\mathrm{g})$ & $\begin{array}{c}\text { CT content } \\
(\mathrm{g} / 100 \mathrm{~g} \text { fraction })\end{array}$ & $\mathrm{mDP}^{c}$ & $\mathrm{PC} / \mathrm{PD}$ & cis/trans \\
\hline 1 & birdsfoot trefoil ${ }^{b}$ & $\mathrm{~F} 2(n=2)$ & 12,16 & $0.98,1.23$ & 76 , nd & 16.1 & $61.8 / 38.2(7)$ & $93 / 7(2)$ \\
\hline 2 & & $\mathrm{~F} 3(n=2)$ & & $0.37,0.19$ & $79(4)$ & 30.6 & $61.0 / 39.0(5)$ & $97.0 / 3.0(4)$ \\
\hline 3 & big trefoil & $\mathrm{F} 2(n=2)$ & 12,19 & $1.60,1.50$ & nd, 86 & 12.7 & $20.6 / 79.4(4)$ & $76.8 / 23.2(4)$ \\
\hline 4 & & $\mathrm{~F} 3(n=2)$ & & $0.50,0.40$ & $96(11)$ & $19(1)$ & $16.0 / 84.0(2)$ & $81 / 19(1)$ \\
\hline 5 & $\begin{array}{l}\text { sericea lespedeza } \\
\quad(\operatorname{lot} 1)\end{array}$ & $\mathrm{F} 2$ & 9 & 0.51 & 63 & nd & $8.1 / 91.9$ & $58.3 / 41.7$ \\
\hline 6 & & F3 & & 0.35 & nd & nd & $5.8 / 94.2$ & $55.3 / 44.7$ \\
\hline 7 & $\begin{array}{l}\text { sericea lespedeza } \\
\quad(\text { lot } 2)\end{array}$ & $\mathrm{F} 2$ & 11 & 0.52 & 71 & 9.3 & $6.5 / 93.5$ & $75.4 / 24.6$ \\
\hline 8 & & F3 & & 0.10 & 96 & 13.7 & $5.9 / 94.1$ & $79.1 / 20.9$ \\
\hline 9 & $\begin{array}{l}\text { HT Mediterranean } \\
\text { trefoil }^{b}\end{array}$ & $\mathrm{~F} 2(n=3)$ & $4.5,17,17$ & $0.24,1.20,1.30$ & nd & nd & $34.0 / 66.0(5)$ & $88.0 / 12.0(4)$ \\
\hline 10 & & F3 $(n=3)$ & & $0.10,0.10,0.32$ & $85(2)$ & 38.2 & $28.0 / 72.0(8)$ & $92.0 / 8.0(2)$ \\
\hline 11 & white clover flower & $\mathrm{F} 2$ & 12 & 1.10 & $75(7)$ & nd & $31.6 / 68.4$ & $57.0 / 43.0$ \\
\hline 12 & & F3 & & 0.18 & $93(5)$ & nd & $2.4 / 97.6$ & $62.4 / 37.6$ \\
\hline 13 & goat willow $^{b}$ & $\mathrm{~F} 2(n=2)$ & $4.5,9$ & $0.83,1.63$ & $94(1)$ & $7.7(0.3)$ & $46.3 / 53.7(0.6)$ & $17.9 / 82.1(0.2)$ \\
\hline 14 & & $\mathrm{~F} 3(n=2)$ & & $0.25,0.49$ & $90(5)$ & 12.1 & $45.0 / 55.0(5)$ & $20.0 / 80.0(2)$ \\
\hline 15 & black currant & $\mathrm{F} 2(n=2)$ & $4.5,12$ & $0.65,2.00$ & $87(16)$ & 7.7 & $8.0 / 92.0(6)$ & $15.9 / 84.1(0.9)$ \\
\hline 16 & & F3 $(n=2)$ & & $0.50,0.64$ & $97(3)$ & 14.9 & $1.5 / 98.5(0.2)$ & $20.0 / 80.0(8)$ \\
\hline
\end{tabular}

${ }^{a}$ Abbreviations used: $\mathrm{mDP}$ : mean degree of polymerization; PC/PD: molar percentages of procyanidins/prodelphinidins; cis/trans: molar percentages of cis/trans flavan-3-ols. Note: Fractions 2 (F2) was eluted with acetone/water (1:1), and fraction 3 (F3) with acetone/water (7:3). Note: the birdsfoot trefoil, big trefoil, and sericea lespedeza extracts were also subjected to Method 3 purification (Table 3 ). ${ }^{b} \mathrm{SD}$ is from replicate fractionations and thiolysis with benzylmercaptan. ${ }^{c} \mathrm{mDP}$ from thiolysis analysis and NMR if necessary when $\mathrm{mDP}<10$, otherwise not determined.

Table 5. Condensed Tannin (CT) Composition from Thiolysis Analysis of Replicate Fractionations $(n=1-2)$ of Plant Materials Purified Twice (P2) by Batch Sephadex LH-20 Chromatography (Method 4) ${ }^{a}$

\begin{tabular}{|c|c|c|c|c|c|c|c|c|}
\hline & plant species & $\begin{array}{c}\text { fraction } \\
\text { (no. of runs) }\end{array}$ & $\begin{array}{c}\text { crude extract used in } \\
\text { P1 (g) }\end{array}$ & $\begin{array}{l}\text { fraction } \\
\text { yield }(\mathrm{g})\end{array}$ & $\begin{array}{c}\text { CT content } \\
(\mathrm{g} / 100 \mathrm{~g} \text { fraction })\end{array}$ & $\mathrm{mDP}$ & $\mathrm{PC} / \mathrm{PD}$ & cis/trans \\
\hline 1 & birdsfoot trefoil ${ }^{b}$ & P2F2 & 12 & 0.30 & 78 & 15.0 & $64.8 / 35.2$ & $91.3 / 8.7$ \\
\hline 2 & big trefoil & $\mathrm{P} 2 \mathrm{~F} 2$ & 12 & 0.40 & 91 & 15.8 & $21.6 / 78.4$ & $82.9 / 17.1$ \\
\hline 3 & & P2F3 & 12 & 0.20 & 87 & 17.9 & $20.7 / 79.3$ & $83.9 / 16.1$ \\
\hline 4 & $\begin{array}{l}\text { sericea lespedeza } \\
\quad(\operatorname{lot} 1)\end{array}$ & P2F2 & 9 & 0.14 & 87 & 11.0 & $6.9 / 93.1$ & $78.3 / 21.7$ \\
\hline 5 & & P2F3 & 9 & 0.19 & 89 & 14.4 & $6.4 / 93.6$ & $80.6 / 19.4$ \\
\hline 6 & $\begin{array}{l}\text { HT Mediterranean } \\
\text { trefoil }^{b}\end{array}$ & $\mathrm{P} 2 \mathrm{~F} 2(n=2)$ & 17 & $0.35(0.20)$ & $98(6)$ & $17.0(2.0)$ & $33.6 / 66.4(0.8)$ & $87.0 / 13.0(1.0)$ \\
\hline 7 & & $\mathrm{P} 2 \mathrm{~F} 3(n=2)$ & 17 & $0.18(0.06)$ & $>99$ & $23.7(0.7)$ & $31.7 / 68.3(0.3)$ & $89.8 / 10.2(0.2)$ \\
\hline 8 & white clover flowers & $\mathrm{P} 2 \mathrm{~F} 2$ & 12 & 0.50 & $>99$ & 11.5 & $1.1 / 98.9$ & $67.9 / 32.1$ \\
\hline 9 & & P2F3 & 12 & 0.20 & $>99$ & 17.7 & $1.0 / 99.0$ & $71.2 / 28.8$ \\
\hline 10 & black currant & $\mathrm{P} 2 \mathrm{~F} 2$ & 12 & 0.87 & $>99$ & 10.4 & $2.8 / 97.2$ & $16.7 / 83.3$ \\
\hline 11 & & P2F3 & 12 & 0.40 & $>99$ & 15.3 & $2.7 / 97.3$ & $19.8 / 80.2$ \\
\hline
\end{tabular}

${ }^{a}$ Abbreviations used: mDP: mean degree of polymerization; PC/PD: molar percentages of procyanidins/prodelphinidins; cis/trans: molar percentages of cis/trans flavan-3-ols. Results for rows 1, 4 and 5, 8 and 9, and 10 and 11 were from repurification of their respective, combined F2 and F3 fractions. Results for rows 2 and 3, and 6 and 7 were from repurification of their respective F2 fraction only. Note: Fractions P2F2 were eluted with acetone/water $(1: 1)$ and fractions $\mathrm{P} 2 \mathrm{~F} 3$ with acetone/water $(7: 3) .{ }^{b} \mathrm{SD}$ is from replicate fractionations $(n=2)$.

$\%$ trans values were also observed in varying degrees in the 7:3 acetone/water fractions eluted in the purification of sainfoin using Methods 1 and 2 (Tables 1 and 2). Most of the mass (69.5\%) was recovered in F0, while the higher purity CT fractions (F2 and F3) accounted for 10.7 and $3.8 \%$ of total mass, respectively, with a $93 \%$ recovery of material from the initial $2 \mathrm{~g}$ applied to the column. This method performs well in comparison with column chromatography methods in regard to both separation and recovery of CTs.

Larger scale purifications of crude extracts (4.5-19 g) from a variety of plant sources were also performed using this method and yielded several fractions with $>1 \mathrm{~g}$ of CTs (Table 4). NMR was used to screen fraction purity (vide infra), and purer fractions were directly analyzed by thiolytic degradation.
Table 4 contains the CT purity and composition results for the higher CT-containing fractions. The \% CT purity ranged from 63 to $97 \%$ CT, the mDP from 7.7 to 16.1 in F2, and from 12.1 to 38.2 in F3 depending on the plant material. The molar \% PD averaged $\sim 4 \%$ higher for the F3 wash fractions and the molar \% trans-flavan-3-ol subunits decreased an average of $\sim 4 \%$. Samples that were less pure were directly repurified in a second purification step, P2, using a similar elution scheme. The purity and CT composition of the repurified fractions (Table 5) ranged from 78 to $>99$ and $\mathrm{mDP}$ values from 11 to 24 . When F2 fractions, which are depleted in longer polymers, were repurified (Table 5, rows 2, 3, 6, and 7), lower $\mathrm{mDP}$ values for P2F3 fractions were obtained. F3 fractions (Table 4) contained the longest polymers (mDP $12-38$ ) with typical purities of $>80 \% \mathrm{CT}$. 


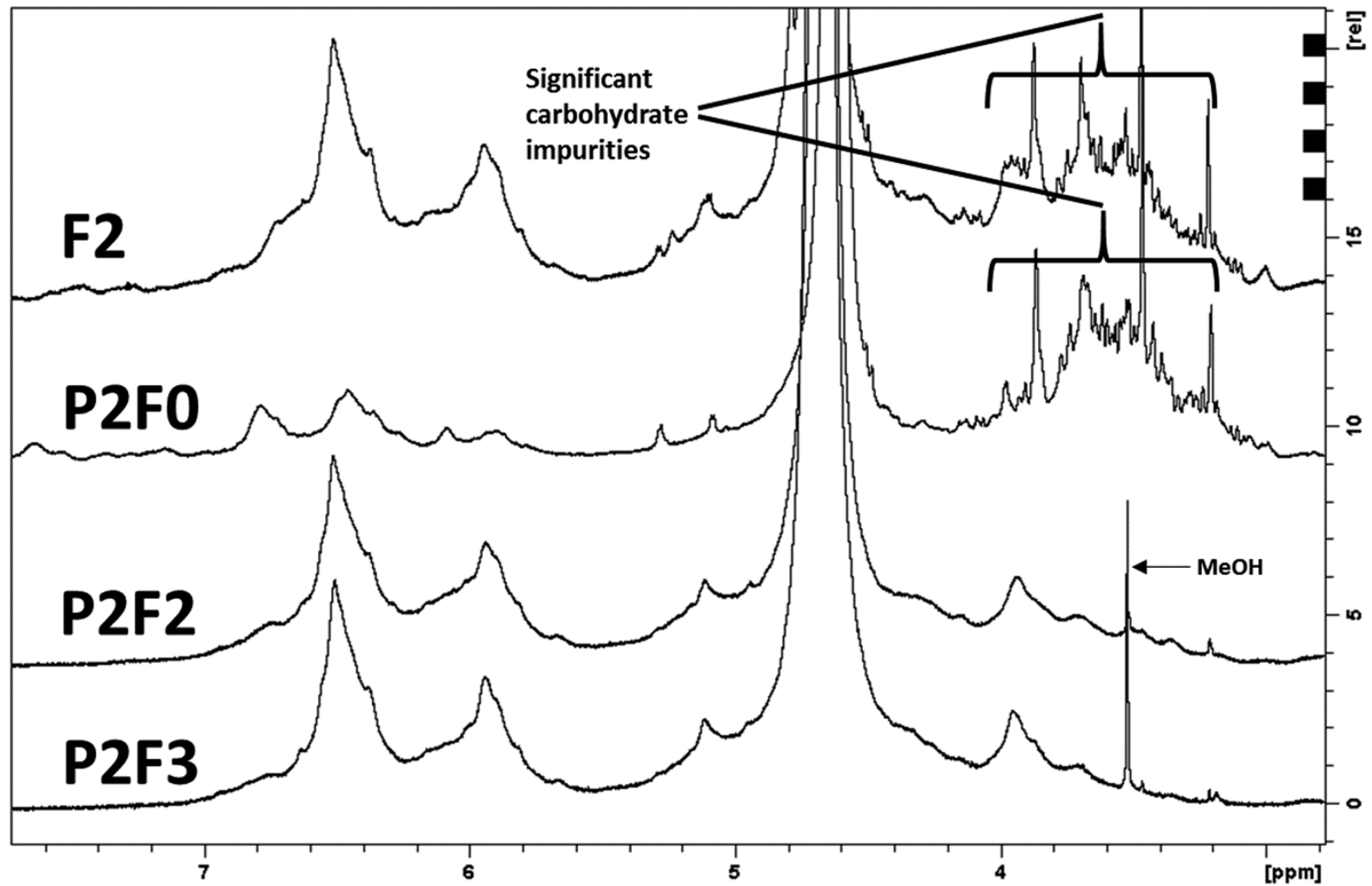

Figure 2. Stacked ${ }^{1} \mathrm{H}$ NMR (360 MHz) spectra of : (F2) material to be repurified by Method 4; (P2F0) the methanol/water (1:1) fraction; (P2F2) the acetone/water (1:1) fraction; and (P2F3) the acetone/water 7:3 fraction. NMR signals arising from carbohydrate impurities are noted for the beginning mixture (spectrum F2) and the methanol/water (1:1) fraction (spectrum P2F0).

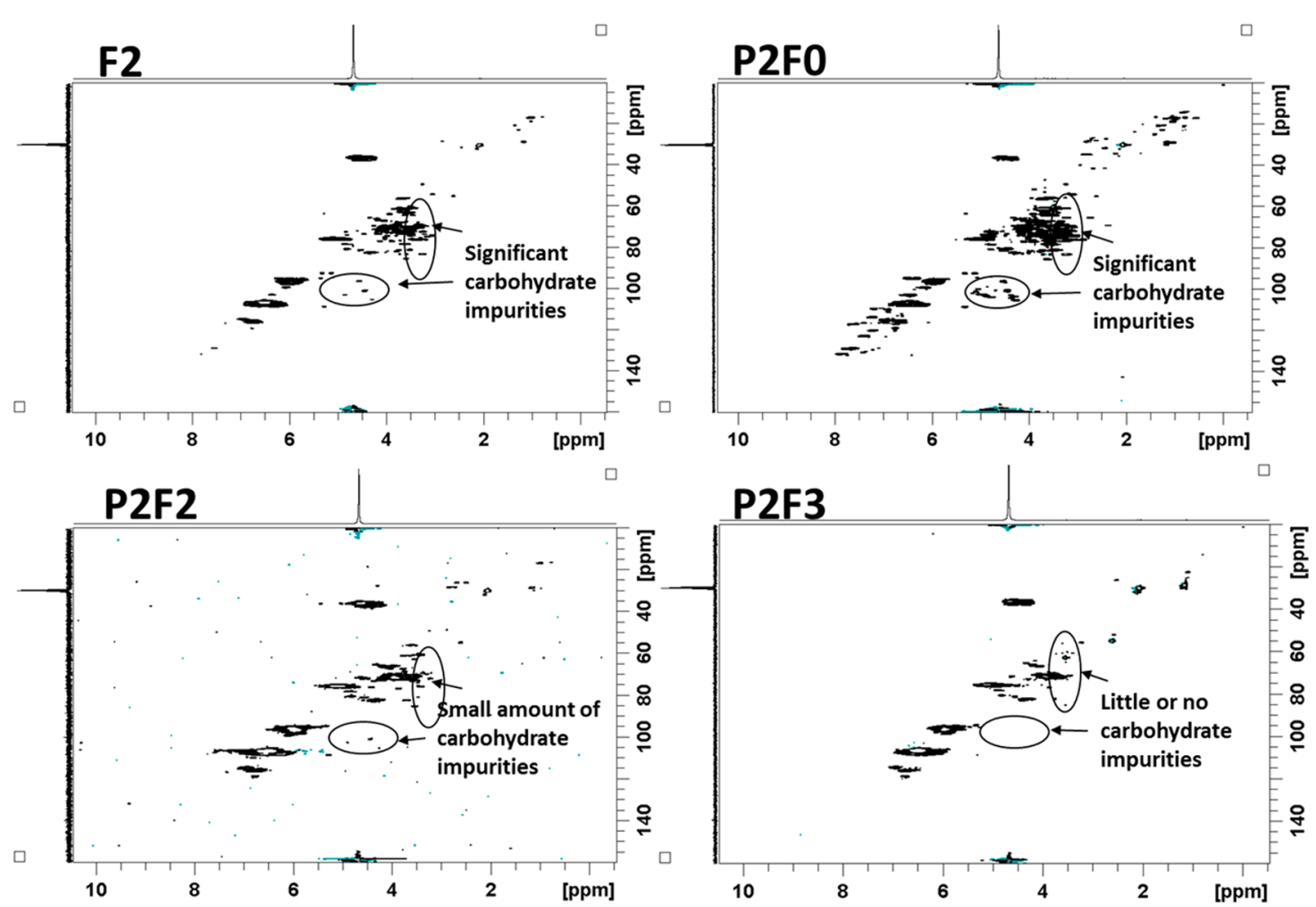

Figure 3. ${ }^{1} \mathrm{H}-{ }^{13} \mathrm{C}$ HSQC NMR spectra of fractions F2, P2F0, P2F2, and P2F3. Fraction F2 is from a previous purification and provided fractions P2F0, P2F2, and P2F3 on subsequent repurification. Fractions P2F2 and P2F3 were subjected to thiolysis degradation and were found to have condensed tannin purities of $72 \%$ and $95 \%$, respectively.

This procedure works well for rapid generation of high purity $\mathrm{CT}$ fractions in gram quantities from a variety of plant sources.
There was no need for a prepurification step and the weights from the two fractions with the highest CT contents, F2 and 
F3, constituted between $9 \%$ and $23 \%$ of crude extract used. The CT polymers can be fractionated according to length and $\mathrm{mDP}$ values are similar to the wide column procedure. Some degree of fractionation of PC/PD and cis/trans-flavan-3ols was also observed. This approach, a time efficient method for purifying crude extracts of 2-19 g, provides up to $2.0 \mathrm{~g}$ quantities of high purity CTs/fraction.

Qualitative Purity Assessment of CT Samples by ${ }^{1} \mathrm{H}$ NMR Spectroscopy. We found that ${ }^{1} \mathrm{H}$ NMR spectroscopy is a very rapid screening method to assess, qualitatively, the purity of these chromatography fractions. Acquisition of a ${ }^{1} \mathrm{H}$ NMR spectrum of a sample is rapid and nondestructive. A variety of NMR solvents can be used in this screening. A 4:1 mixture of $\mathrm{D}_{2} \mathrm{O} /$ acetone- $d_{6}$ works well, as carbohydrate signals, the major type of biomolecule impurity, provide sharp, easily distinguishable signals. For example, the ${ }^{1} \mathrm{H}$ NMR spectrum of the impure sample is given in Figure 2 (spectrum F2), and shows signals arising from carbohydrate impurities between 3 and 4 ppm. This fraction underwent repurification to give rise to three further fractions: fraction P2F0, eluted with 1:1 methanol/water; fraction P2F2, eluted with 1:1 acetone/water; and fraction P2F3, eluted with 7:3 acetone/water. Examination of the ${ }^{1} \mathrm{H}$ NMR spectra of these fractions (Figure 2) shows fraction P2F0 containing a significant amount of the carbohydrate impurity whereas fractions P2F2 and P2F3 show little or no sharp signals in the carbohydrate region of the spectrum (3-4 ppm). The lack of observed carbohydrate signals in the ${ }^{1} \mathrm{H}$ NMR spectrum triggers analysis of the sample forward into a second purity screen using two-dimensional ${ }^{1} \mathrm{H}-{ }^{13} \mathrm{C}$ HSQC NMR (2D NMR) spectroscopy.

Visual Purity Assessment and Compositional Analysis of CT Samples by ${ }^{1} \mathrm{H}-{ }^{13} \mathrm{C}$ HSQC NMR (2D NMR) Spectroscopy. To illustrate the power of this method, the 2D NMR spectra of fractions F2, P2F0, P2F2, and P2F3 are given in Figure 3 (a P2F1 fraction was not eluted in this particular repurification scheme). The spectrum for the starting impure fraction F2 clearly shows a wealth of carbohydrate impurities. The 2D NMR spectrum of fraction P2F0 shows enhanced carbohydrate impurities, relative to the CT cross-peak signals in spectrum F2, indicating a large portion of the carbohydrates present in impure fraction F2 were captured in the 1:1 methanol/water fraction of the second purification. Spectra of fractions P2F2 and P2F3 showed relatively low levels of impurities (non-CT attributed cross-peak signals). Although this second NMR screening method requires an overnight acquisition, it provides greater detail of the presence and identity of impurities still residing in the sample, some of which (carbohydrate- and lipid-derived) avoid detection by UV absorption-based detectors commonly used for analysis in CT chromatography. Once the CT sample passes this visual purity assessment, the sample is forwarded to thiolytic degradation, where quantitation of the structural features determined by $2 \mathrm{D}$ NMR (PC/PD and cis/trans ratios) ${ }^{23}$ are confirmed and additional features $(\mathrm{mDP}$, terminal and extension unit identification) and purity assessment of the sample can be determined.

In summary, conventional chromatography on a Toyopearl HW-50F column separated CTs according to polymer size (mDPs of 2-95) with acetone/water (7:3) and acetone elution. Some separation occurred of CTs rich in PC and PD subunits when methanol/water (1:1) and acetone/water (7:3) were used, but this method required a prepurification step, extended elution times and yielded CTs in smaller (mg) quantities. In contrast, fast eluent flow rates from a short, wide
Sephadex LH-20 column readily removed contaminating carbohydrates, phenolic and other compounds from $10 \mathrm{~g}$ of crude plant extracts within 4-5 h. This required extensive rinsing with water before eluting the CTs in F1 to give yields of $150-800 \mathrm{mg}$ with purities of $20-63 \%$ CT (mostly oligomeric CTs). Elution of F2 generated 190-1200 mg quantities of 60-100\% CT (mostly polymeric CTs). The results presented are based on seven plant materials, obtained by five people conducting up to 10 separate fractionations on the same column. An alternative method, utilizing a different adsorption and solvent elution scheme, also enabled rapid purification of CTs without the need for a prepurification step and provided gram quantities of highly pure CTs ( 80 to $>99 \%$ ). The wide column and batch chromatography protocols (Methods 3 and 4) are simple to run and can be performed effectively by novice researchers. The purest fractions from the batch method provided larger quantities of CTs with higher $\mathrm{mDP}$ values (up to 38) (Table 5) than the wide Sephadex LH-20 column (up to 30) (Table 3). The decision on whether to use Method 3 (Sephadex LH-20 is reused) or Method 4 (Sephadex LH-20 is used once) will depend on laboratory resources. If CTs of more focused $\mathrm{mDP}$ ranges are required, smaller quantities of such Sephadex LH-20 fractions (e.g., $2 \mathrm{~g}$ ) could then be applied to a Toyopearl HW-50F column to give $10-200 \mathrm{mg}$ quantities of CTs with $\mathrm{mDP}$ values ranging from 2 to 95 . Given several recent reports that linked CT size to bioactivity, ${ }^{1,6-8,48-50}$ this approach will assist researchers in isolating a wide range of high purity CTs that cover oligomers to polymers for biological studies. Presented here are details of procedures we have used to obtain highly pure CTs and, in our opinion, which are the best methods to date to characterize these CT materials. We emphasize here that, given the diversity of CT structures (flavan-3-ol subunits, $\mathrm{mDP}$, and interflavan linkages), we have not found a single, generic set of conditions that will provide large-scale optimal separation of CTs from all plant materials investigated in one operation. In some cases, repeating the purification protocol was necessary to achieve the desired purity. The approaches detailed here provide a set of methods which proved successful in obtaining substantial quantities of CTs, leading to the production of a library of purified CTs with diverse structural composition to investigate their structureactivity relationships. The inclusion of mass yields of purified CT fractions obtained from dried plant materials will allow researchers to project the quantity of dried plant material needed for extraction and purification to obtain targeted amounts of CTs for their proposed studies.

\section{ASSOCIATED CONTENT}

\section{Supporting Information}

The Supporting Information is available free of charge on the ACS Publications website at DOI: 10.1021/acs.jafc.7b03489.

Specific example for preparation of a crude plant extract; detailed description of "wide column" Sephadex LH-20 chromatography; re-purification of a sericea lespedeza CT fraction for demonstration of ${ }^{1} \mathrm{H}$ NMR spectroscopy as a CT purity screening tool; applied and recovered masses from chromatography of a crude sainfoin extract on standard Sephadex LH-20 or Toyopearl HW-50F columns; flavan-3-ol subunit composition of CT from sainfoin separated on standard Sephadex LH-20 or Toyopearl HW-50F columns; flavan-3-ol subunit compositions of CT fractions after "wide column" Sephadex 
LH-20 chromatography; weight, purity and composition of CT from thiolysis degradation of replicate purified fractions of sainfoin using Sephadex LH-20 batch chromatography; flavan-3-ol subunits composition from fractionations purified once and twice using Sephadex LH-20 batch chromatography; summary of conditions suited for isolating different CTs; set-up for "wide column" Sephadex LH-20 fractionation. (PDF)

\section{AUTHOR INFORMATION}

\section{Corresponding Authors}

*(I.M.-H.) Tel: +44 118378 6714. Fax: +44 1189352421.

E-mail: i.mueller-harvey@reading.ac.uk.

*(W.E.Z.) Tel: +1 608-890-0071. Fax: +1 608-890-0076.

E-mail: wayne.zeller@ars.usda.gov.

ORCID

Irene Mueller-Harvey: 0000-0001-6613-072X

Wayne E. Zeller: 0000-0002-1883-4519

\section{Funding}

This work was supported by two European Union Marie Curie training networks ("HealthyHay" MRTN-CT-2006-035805 and "LegumePlus" PITN-GA-2011-289377) and funded in part by a USDA-ARS specific cooperative Agreement No. 58-3655-0$155 \mathrm{~F}$ with the University of Reading, U.K.

\section{Notes}

Mention of trade names or commercial products in this article is solely for the purpose of providing specific information and does not imply recommendation or endorsement by the U.S. Department of Agriculture.

The authors declare no competing financial interest.

\section{ACKNOWLEDGMENTS}

We acknowledge the kind supply of plant materials (big trefoil, birdsfoot trefoil, high tannin Mediterranean birdsfoot trefoil, goat willow, black currant leaves) from John Grabber (USDFRC). We thank Jamison Robe (USDFRC) for her assistance in purifications.

\section{ABBREVIATIONS USED}

C, catechin; CT(s), condensed tannin(s); EC, epicatechin; EGC, epigallocatechin; $\mathrm{mDP}$, mean degree of polymerization; PC, procyanidins; PD, prodelphinidins; \% CT, g CT $\times 100$ / $100 \mathrm{~g}$ of fraction

\section{REFERENCES}

(1) Neilson, A. P.; O'Keefe, S. F.; Bolling, B. W. High-molecularweight proanthocyanidins in foods: overcoming analytical challenges in pursuit of novel dietary bioactive components. Annu. Rev. Food Sci. Technol. 2016, 7, 43-54.

(2) Min, B. R.; Barry, T. N.; Attwood, G. T.; McNabb, W. C. The effect of condensed tannins on the nutrition and health of ruminants fed fresh temperate forages: a review. Anim. Feed Sci. Technol. 2003, 106, 3-19.

(3) Mueller-Harvey, I. Unravelling the conundrum of tannins in animal nutrition and health. J. Sci. Food Agric. 2006, 86, 2010-2037.

(4) Naumann, H. D.; Muir, J. P.; Lambert, B. D.; Tedeschi, L. O.; Kothmann, M. M. Condensed tannins in the ruminant environment: A perspective on biological activity. J. Agric. Sci. 2013, 1, 8-20.

(5) Piluzza, G.; Sulas, L.; Bullitta, S. Tannins in forage plants and their role in animal husbandry and environmental sustainability: a review. Grass Forage Sci. 2014, 69, 32-48.

(6) Ropiak, H. M.; Lachmann, P.; Ramsay, A.; Green, R. J.; MuellerHarvey, I. 2017. Identification of structural features of condensed tannins that affect protein aggregation. PLoS One 2017, 12 (1), e0170768.

(7) Huyen, N. T.; Fryganas, C.; Uittenbogaard, G.; Mueller-Harvey, I.; Verstegen, M. W. A.; Hendriks, W. H.; Pellikaan, W. F. Structural features of condensed tannins affect in vitro ruminal methane production and fermentation characteristics. J. Agric. Sci. 2016, 154, 1474-1487.

(8) Quijada, J.; Fryganas, C.; Ropiak, H. M.; Ramsay, A.; MuellerHarvey, I.; Hoste, H. Anthelmintic activities against Haemonchus contortus or Trichostrongylus colubriformis from small ruminants are influenced by structural features of condensed tannins. J. Agric. Food Chem. 2015, 63, 6346-6354.

(9) Zeller, W. E.; Sullivan, M. L.; Mueller-Harvey, I.; Grabber, J. H.; Ramsay, A.; Drake, C.; Brown, R. H. Protein precipitation behavior of condensed tannins from Lotus pedunculatus and Trifolium repens with different mean degrees of polymerization. J. Agric. Food Chem. 2015, $63,1160-1168$.

(10) Williams, A. R.; Klaver, E. J.; Laan, L. C.; Ramsay, A.; Fryganas, C.; Difborg, R.; Kringel, H.; Reed, J. D.; Mueller-Harvey, I.; Skov, S.; van Die, I.; Thamsborg, S. M. Co-operative suppression of inflammatory responses in human dendritic cells by proanthocyanidins and products from the parasitic nematode Trichuris suis. Immunology 2017, 150, 312-328.

(11) Feliciano, R. P.; Meudt, J. J.; Shanmuganayagam, D.; Krueger, C. G.; Reed, J. D. Ratio of "A-type" to "B-type" proanthocyanidin interflavan bonds affects extra-intestinal pathogenic Escherichia coli invasion of gut epithelial cells. J. Agric. Food Chem. 2014, 62, 39193925.

(12) Salminen, J.-P.; Karonen, M. Chemical ecology of tannins and other phenolics: we need a change in approach. Funct. Ecol. 2011, 25, $325-338$.

(13) Gu, L.; Kelm, M.; Hammerstone, J. F.; Beecher, G.; Cunningham, D.; Vannozzi, S.; Prior, R. L. Fractionation of polymeric procyanidins from lowbush blueberry and quantification of procyanidins in selected foods with an optimized normal-phase HPLC-MS fluorescent detection method. J. Agric. Food Chem. 2002, 50, 48524860.

(14) Li, C.; Trombley, J. D.; Schmidt, M. A.; Hagerman, A. E. Preparation of an acid butanol standard from fresh apples. J. Chem. Ecol. 2010, 36, 453-460.

(15) Guadalupe, Z.; Soldevilla, A.; Saenz-Navajas, M.-P.; Ayestaran, B. Analysis of polymeric phenolics in red wines using different techniques combined with gel permeation chromatography fractionation. J. Chromatogr. A 2006, 1112, 112-120.

(16) Vidal, S.; Francis, L.; Guyot, S.; Marnet, N.; Kwiatkowski, M.; Gawel, R.; Cheynier, V.; Waters, E. J. The mouth-feel properties of grape and apple proanthocyanidins in a wine-like medium. J. Sci. Food Agric. 2003, 83, 564-573.

(17) Bindon, K. A.; Smith, P. A.; Holt, H.; Kennedy, J. A. Interaction between grape-derived proanthocyanidins and cell wall material. 2 . Implications for vinification. J. Agric. Food Chem. 2010, 58, 1073610746.

(18) Li, H.-J.; Deinzer, M. L. Structural identification and distribution of proanthocyanidins in 13 different hops. J. Agric. Food Chem. 2006, $54,4048-4056$

(19) Kennedy, J. A.; Taylor, A. W. Analysis of proanthocyanidins by high-performance gel permeation chromatography. J. Chromatogr. A 2003, 995, 99-107.

(20) Foo, L. Y.; Porter, L. J. The phytochemistry of proanthocyanidin polymers. Phytochemistry 1980, 19, 1747-1754.

(21) Grabber, J.; Zeller, W. E.; Mueller-Harvey, I. Acetone enhances the direct analysis of procyanidin- and prodelphinidin-based condensed tannins in Lotus species by the butanol-HCl-iron assay. J. Agric. Food Chem. 2013, 61, 2669-2678.

(22) Gea, A.; Stringano, E.; Brown, R. H.; Mueller-Harvey, I. In situ analysis and structural elucidation of sainfoin (Onobrychis viciifolia) tannins for high throughput germplasm screening. J. Agric. Food Chem. 2011, 59, 495-503. 
(23) Zeller, W. E.; Ramsay, A.; Ropiak, H. M.; Fryganas, C.; MuellerHarvey, I.; Brown, R. H.; Drake, C.; Grabber, J. H. ${ }^{1} \mathrm{H}^{-13} \mathrm{C}$ HSQC NMR spectroscopy for estimating procyanidin/prodelphinidin and cis/ trans flavanol ratios of condensed tannin fractions: correlation with thiolysis. J. Agric. Food Chem. 2015, 63, 1967-1973.

(24) Giner-Chavez, B.; Van Soest, P. J.; Robertson, J. B.; Pell, A. N.; Lascano, C. E.; Reed, J. D. A method for isolating condensed tannins from crude plant extracts with trivalent ytterbium. J. Sci. Food Agric. 1997, 74, 359-368.

(25) Alvarez del Pino, M. C.; Hervas, G.; Mantecon, A. R.; Giraldez, F. J.; Frutos, P. Comparison of biological and chemical methods, and internal and external standards, for assaying tannins in Spanish shrub species. J. Sci. Food Agric. 2005, 85, 583-590.

(26) Schofield, P.; Mbugua, D. M.; Pell, A. N. 2001. Analysis of condensed tannins; a review. Anim. Feed Sci. Technol. 2001, 91, 21-40.

(27) Kraus, T. E. C.; Yu, Z.; Preston, C. M.; Dahlgren, R. A.; Zasoski, R. J. Linking chemical reactivity and protein precipitation to structural characteristics of foliar tannins. J. Chem. Ecol. 2003, 29, 703-730.

(28) Le Bourvellec, C.; Renard, C. M. G. C. Interactions between polyphenols and macromolecules: quantification methods and mechanisms. Crit. Rev. Food Sci. Nutr. 2012, 52, 213-248.

(29) Porter, L. J. Flavans and proanthocyanidins. In The Flavanoids: Advances in research since 1980; Harborne, J. B., Ed.; Springer US: Boston, MA, 1988; pp 21-62.

(30) Stringano, E.; Hayot Carbonero, C.; Smith, L. M. J.; Brown, R. H.; Mueller-Harvey, I. Proanthocyanidin diversity in the EU 'HealthyHay' sainfoin (Onobrychis viciifolia) germplasm collection. Phytochemistry 2012, 77, 197-208.

(31) Ropiak, H. M.; Ramsay, A.; Mueller-Harvey, I. Condensed tannins in extracts from European medicinal plants and herbal products. J. Pharm. Biomed. Anal. 2016, 121, 225-231.

(32) Roberts, C. A.; Beuselinck, P. R.; Ellersieck, M. R.; Davis, D. K.; McGraw, R. L. Quantification of tannins in birdsfoot trefoil germplasm. Crop Sci. 1993, 33, 675-679.

(33) Stringano, E.; Cramer, R.; Hayes, W.; Smith, C.; Gibson, T.; Mueller-Harvey, I. Deciphering the complexity of sainfoin (Onobrychis viciifolia) proanthocyanidins by MALDI-TOF mass spectrometry with a judicious choice of isotope patterns and matrices. Anal. Chem. 2011, 83, 4147-4153.

(34) Dubois, M.; Gilles, K. A.; Hamilton, J. K.; Rebers, P. A.; Smith, F. Colorimetric method for determination of sugars and related substances. Anal. Chem. 1956, 28, 350-356.

(35) Hagerman, A. E.; Butler, L. G. Condensed tannin purification and characterization of tannin-associated proteins. J. Agric. Food Chem. 1980, 28, 947-952.

(36) Marais, J. P. J.; Mueller-Harvey, I.; Brandt, E. V.; Ferreira, D. Polyphenols, condensed tannins and other natural products in Onobrychis viciifolia (sainfoin). J. Agric. Food Chem. 2000, 48, 34403447.

(37) Le Bourvellec, C.; Guyot, S.; Renard, C. M. G. C. 2009. Interactions between apple (Malus $\times$ domestica Borkh.) polyphenols and cell walls modulate the extractability of polysaccharides. Carbohydr. Polym. 2009, 75, 251-261.

(38) Regos, I.; Urbanella, A.; Treutter, D. Identification and quantification of phenolic compounds from the forage legume sainfoin (Onobrychis viciifolia). J. Agric. Food Chem. 2009, 57, 5843-5852.

(39) Furlan, A. L.; Jobin, M.-L.; Pianet, I.; Dufourc, E. J.; Gean, J. Flavanol/lipid interaction: a novel molecular perspective in the description of wine astringency \& bitterness and antioxidant action. Tetrahedron 2015, 71, 3143-3147.

(40) Le Bourvellec, C.; Le Quere, J.-M.; Renard, C. M. G. C. Impact of noncovalent interactions between apple condensed tannins and cell walls on their transfer from fruit to juice: studies in model suspensions and application. J. Agric. Food Chem. 2007, 55, 7896-7904.

(41) Putman, L. J.; Butler, L. G. Separation of high molecular weight sorghum procyanidins by high-performance liquid chromatography. $J$. Agric. Food Chem. 1989, 37, 943-946.

(42) Ramsay, A.; Williams, A. R.; Thamsborg, S. M.; Mueller-Harvey, I. Galloylated proanthocyanidins from shea (Vitellaria paradoxa) meal have potent anthelmintic activity against Ascaris suum. Phytochemistry 2016, 122, 146-153.

(43) He, Q.; Shi, B.; Yao, K. Interactions of gallotannins with proteins, amino acids, phospholipids and sugars. Food Chem. 2006, 95, 250-254.

(44) Willker, W.; Leibfritz, D. Assignment of mono- and polyunsaturated fatty acids in lipids of tissues and body fluids. Magn. Reson. Chem. 1998, 36, S79-S84.

(45) Still, W. C.; Kahn, M.; Mitra, A. Rapid chromatographic technique for preparative separations with moderate resolution. J. Org. Chem. 1978, 43, 2923-2925.

(46) Kommuru, D. S.; Barker, T.; Desai, S.; Burke, J. M.; Ramsay, A.; Mueller-Harvey, I.; Miller, J. E.; Mosjidis, J. A.; Kamisetti, N.; Terrill, T. H. Use of pelleted sericea lespedeza (Lespedeza cuneata) for natural control of coccidia and gastrointestinal nematodes in weaned goats. Vet. Parasitol. 2014, 204, 191-198.

(47) Ghisalbert, E. L. Detection and Isolation of Bioactive Natural Products. In Bioactive Natural Products: Detection, Isolation, and Structural Determination, 2nd ed.; Colegate, S. M., Molyneux, R. J., Eds.; CRC Press, Boca Raton, FL, 2008; Ch. 2, pp 11-76.

(48) Hatew, B.; Stringano, E.; Mueller-Harvey, I.; Hendriks, W. H.; Hayot Carbonero, C.; Smith, L. M. J.; Pellikaan, W. F. Impact of variation in structure of condensed tannins from sainfoin (Onobrychis viciifolia) on in vitro ruminal methane production and fermentation characteristics. J. Anim. Physiol. Anim. Nutr. 2016, 100, 348-360.

(49) Desrues, O.; Fryganas, C.; Ropiak, H. M.; Mueller-Harvey, I.; Enemark, H. L.; Thamsborg, S. M. Impact of chemical structure of flavanol monomers and condensed tannins on in vitro anthelmintic activity against bovine nematodes. Parasitology 2016, 143, 444-454.

(50) Mena, P.; Calani, L.; Bruni, R.; Del Rio, D. Bioactivation of high-molecular-weight polyphenols by the gut microbiome. In DietMicrobe Interactions in the Gut; Effects on Human Health and Disease, 1st ed.; Touhy, K., Del Rio, D., Eds.; Academic Press: San Diego, CA. 2015; Ch. 6, pp 73-101. 


\section{Supplementary Materials for:}

Facile Purification of Milligram to Gram Quantities of Condensed Tannins According to Mean Degree of Polymerization and Flavan-3-ol Subunit Composition

Ron H. Brown, $†$ Irene Mueller-Harvey,$\dagger^{*}$ Wayne E. Zeller,$\ddagger^{*}$ Laurie Reinhardt, $\ddagger$ Elisabetta Stringano, $\dagger$ An Gea, $\uparrow$ Christopher Drake, $\uparrow$ Honorata M. Ropiak, $\uparrow$ Christos Fryganas, $\uparrow$ Aina Ramsay, $\uparrow$ and Emily E. Hardcastleł

†School of Agriculture, Policy and Development, University of Reading, P O Box 236, Reading RG6 6AT, U.K.

‡U.S. Dairy Forage Research Center, Agricultural Research Service, U.S. Department of Agriculture, 1925 Linden Drive, Madison, Wisconsin 53706, United States 


\section{Table of Contents}

\section{Methods and Materials:}

1. Specific Example for Preparation of a Crude Plant Extract..........................................................

2. Detailed Description of 'Wide column' Sephadex LH-20 Chromatography (Method 3).........................4

3. Re-Purification of a Sericea Lespedeza CT Fraction for Demonstration of ${ }^{1} \mathrm{H}$ NMR Spectroscopy as a CT

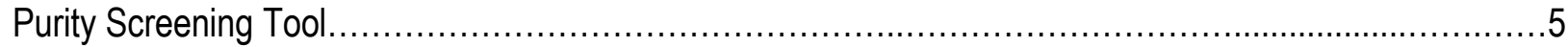

\section{Results:}

Table S1. Applied and recovered masses from chromatography of a crude sainfoin extract (Cotswold Common; $379.5 \mathrm{mg}$ ) on standard columns (120 mm length x $30 \mathrm{~mm}$ i.d.) of either Sephadex LH-20 or Toyopearl HW-50F (Method 2) 6

Table S2. Flavan-3-ol subunit composition (molar percentages) of condensed tannins from sainfoin (Cotswold Common) separated on either Sephadex LH-20 or Toyopearl HW-50F columns (Method 2)

Table S3. Flavan-3-ol subunit compositions (molar percentages) of condensed tannin fractions obtained by wide Sephadex LH-20 column chromatography (Method 3).....

Table S4. Weight, purity and composition of condensed tannins (CT) from thiolysis degradation of replicate purified $(n=2)$ fractions of sainfoin ( $2 \mathrm{~g}$ crude extract) using Sephadex LH-20 batch chromatography (Method 4)......

Table S5: Flavan-3-ol subunit (molar percentages) composition from fractionations purified once using Sephadex LH-20 batch chromatography (Method 4).

Table S6. Flavan-3-ol subunit (molar percentages) composition from fractionations purified twice using Sephadex LH-20 batch chromatography (Method 4)

Table S7: Summary of conditions suited for isolating different CTs.

\section{Figure:}

Figure S1. Set up for wide Sephadex LH-20 column fractionation (Method 3). 14 


\section{Methods and Materials:}

\section{Specific Example for Preparation of a Crude Plant Extract.}

Finely ground sericea lespedeza $(50.1 \mathrm{~g})$ was transferred to a $500 \mathrm{~mL}$ Erlenmeyer flask equipped with a magnetic stir bar and a mixture of 7:3 acetone/water $(300 \mathrm{~mL})$ was added. The mixture was rapidly stirred for $30 \mathrm{~min}$ and then filtered through a $600 \mathrm{~mL}$ Buchner funnel equipped with a filter paper. The retained solids were subjected to this extraction process two additional times and the combined filtrates were concentrated under reduced pressure on a rotary evaporator $\left(<35{ }^{\circ} \mathrm{C}\right)$ to remove acetone. Dichloromethane $(200 \mathrm{~mL}$ ) was added to the resulting aqueous layer and gently stirred (to avoid formation of an emulsion) using a magnetic stir bar ( $30 \mathrm{~min}$ ). The layers were transferred to a separatory funnel and the aqueous layer was re-subjected to dichloromethane extraction two additional times $(2 \times 150 \mathrm{~mL})$. The aqueous layer was concentrated under reduced pressure on a rotary evaporator $\left(<35^{\circ} \mathrm{C}\right)$ to remove traces of dichloromethane and then freeze-dried to give $10.7 \mathrm{~g}$ of a tan solid and labeled as crude extract. 


\section{Detailed Description of 'Wide column' Sephadex LH-20 Chromatography (Method 3).}

1. Sephadex $\mathrm{LH}-20(50 \mathrm{~g})$ was left to swell in water $(200 \mathrm{~mL})$ for at least 4 hours.

2. The resulting slurry was then poured into a glass column (400 mm length $\times 65 \mathrm{~mm}$ i.d.) equipped with a sintered-glass frit followed by water $(1 \mathrm{~L})$.

3. The slurry was allowed to settle and the excess water was drained to a level of $10 \mathrm{~mm}$ above the resulting resin bed $(70 \mathrm{~mm}$ length $\times 65 \mathrm{~mm}$ i.d.).

4. Plant samples $(50 \mathrm{~g})$ were extracted with acetone/water $(7: 3, \mathrm{v} / \mathrm{v} ; 500 \mathrm{~mL})$ by stirring at r.t. for 40 $\min$. The extract was filtered, extracted in a separatory funnel with dichloromethane $(250 \mathrm{~mL})$, the upper, aqueous phase concentrated on a rotary evaporator to remove acetone and centrifuged to remove any insoluble material.

5. The aqueous phase containing ca $10 \mathrm{~g}$ of this crude plant extract was stored in the freezer overnight and thawed the next day, diluted with deionized water $(1 \mathrm{~L})$, filtered and water $(1 \mathrm{~L})$ added.

6. This solution was transferred to a separatory funnel, which was placed above the glass column so that the funnel outlet touched the side of the glass column.

7. The funnel stopcock was opened and the CT solution allowed to flow, slowly initially, along the inside of the column without disturbing the resin bed, and then rapidly once sufficient liquid was above the column, onto the Sephadex LH-20 resin.

8. The column stopcock was opened to give a fast flow (ca $40 \mathrm{~mL} / \mathrm{min}$ ) through the column and sample application was stopped when the solvent reached ca $10 \mathrm{~mm}$ above the resin.

9. Then $2 L$ of deionized water was added to the funnel and the column was rinsed until the eluent was clear (flow rate: 40 to $50 \mathrm{~mL} / \mathrm{min}$ ) and rinsing was stopped when the water level was $10 \mathrm{~mm}$ above the resin.

10. Acetone/water $(3: 7, v / v, 1 \mathrm{~L})$ was then added to the separatory funnel and the first $200 \mathrm{~mL}$ of eluent were discarded.

11. The CTs were collected at $15 \mathrm{~mL} / \mathrm{min}$ during the next $500 \mathrm{~mL}$ elution giving Fraction 1 (vanillin/ $\mathrm{HCl}$ was used to test for CTs in eluent). ${ }^{1}$

12. The remaining solvent was used to rinse the column and the flow was stopped again when the solvent reached $10 \mathrm{~mm}$ above the resin.

13. Fraction 2 was similarly eluted with acetone/water $(1: 1, v / v, 1 \mathrm{~L})$, where the first $200 \mathrm{~mL}$ of eluent was discarded and CTs were collected at $25 \mathrm{~mL} / \mathrm{min}$ during the next $300 \mathrm{~mL}$ of elution.

14. The column was reconditioned with water $(2 \mathrm{~L})$ at $25 \mathrm{~mL} / \mathrm{min}$.

15. Columns could be re-used approximately 10 times without losing separation efficiency as monitored by thiolysis of each fraction. Occasional rinsing of the resin with acetone/water $(8: 2, \mathrm{v} / \mathrm{v})$ extended column life when necessary.

1. Schofield, P.; Mbugua, D. M.; Pell, A. N. 2001. Analysis of condensed tannins; a review. Anim. Feed Technol. 2001, 91, 21-40. 


\section{Repurification of a Sericea Lespedeza CT Fraction for Demonstration of ${ }^{1} \mathrm{H}$ NMR Spectroscopy as}

\section{a CT Purity Screening Tool.}

An impure fraction from a previous Lespedeza cuneata CT purification attempt (1.2 g, fraction F2) was dissolved in methanol/water (1:1, v/v; $60 \mathrm{~mL})$ and Sephadex LH-20 resin was added in small portions with stirring until a thick slurry developed with the consistency of wet sand (a total of $13.1 \mathrm{~g}$ Sephadex LH-20 was added). The resin was transferred to a $600 \mathrm{~mL}$ coarse sintered-glass funnel equipped with a filter paper, suspended in the solvent (listed below), allowed to stand for 5-10 min and then vacuum-filtered using the following sequence of solvents: methanol/water $(1: 1, \mathrm{v} / \mathrm{v} ; 5 \times 50 \mathrm{~mL})$ to give fraction P2F0; acetone/water (1:1, v/v; $5 \times 50 \mathrm{~mL})$ to give fraction P2F2; acetone/water $(7: 3, \mathrm{v} / \mathrm{v} ; 5 \times 50 \mathrm{~mL})$ to give fraction P2F3. Fractions were concentrated $\angle 35^{\circ} \mathrm{C}$ to remove the acetone and the resulting aqueous phases freeze-dried (Yields: fraction P2F0, 435 mg; fraction P2F2, 524 mg; fraction P2F3, 99 mg). 
Table S1. Applied and recovered masses from chromatography of a crude sainfoin extract (Cotswold Common; $379.5 \mathrm{mg}$ ) on standard columns (120 mm length $\times 30 \mathrm{~mm}$ i.d.) of either Sephadex LH-20 or Toyopearl HW-50F (Method 2).

\begin{tabular}{|c|c|c|c|c|c|}
\hline Columns and eluents & Fraction & $\begin{array}{l}\text { Weight } \\
\text { (mg) }\end{array}$ & $\begin{array}{c}\text { Percentage of } \\
\text { applied sample (\%) }\end{array}$ & $\begin{array}{c}\text { Percentage of recovered } \\
\text { extract \% }\end{array}$ & $\begin{array}{c}\text { Sum per eluent } \\
\%\end{array}$ \\
\hline \multicolumn{6}{|l|}{ Sephadex LH-20 } \\
\hline \multirow[t]{3}{*}{ Water } & S1 & 40.4 & 10.65 & 11.4 & \\
\hline & S2 & 4.8 & 1.27 & 1.4 & \\
\hline & S3 & 2.6 & 0.69 & 0.7 & 13.5 \\
\hline \multirow[t]{3}{*}{ Methanol/water $(1: 1, \mathrm{v} / \mathrm{v})$} & S4 & 4.8 & 1.27 & 1.4 & \\
\hline & S5 & 13.6 & 3.59 & 3.8 & \\
\hline & S6 & 10.9 & 2.87 & 3.1 & 8.3 \\
\hline \multirow[t]{4}{*}{ Acetone/water $(7: 3, \mathrm{v} / \mathrm{v})$} & S7 & 118.7 & 31.29 & 33.4 & \\
\hline & S8a & 105.5 & 27.81 & 29.7 & \\
\hline & $\mathrm{s} 8 \mathrm{~b}$ & 32.6 & 8.59 & 9.2 & \\
\hline & S9 & 18 & 4.75 & 5.1 & 77.4 \\
\hline Acetone & S10 & 3.2 & 0.84 & 0.9 & 1.1 \\
\hline Recovery & & 355.1 & 93.62 & 100.0 & \\
\hline \multicolumn{6}{|l|}{ Toyopearl HW-50F } \\
\hline \multirow[t]{3}{*}{ Water } & T1 & 28.0 & 7.38 & 10.4 & \\
\hline & $\mathrm{T} 2$ & 4.5 & 1.19 & 1.7 & \\
\hline & T3 & 1.5 & 0.40 & 0.6 & 12.7 \\
\hline \multirow[t]{3}{*}{ Methanol/water $(1: 1, \mathrm{v} / \mathrm{v})$} & T4 & 2.5 & 0.66 & 0.9 & \\
\hline & T5 & 4.9 & 1.29 & 1.8 & \\
\hline & T6 & 6.1 & 1.61 & 2.3 & 5.0 \\
\hline \multirow[t]{4}{*}{ Acetone/water $(7: 3, \mathrm{v} / \mathrm{v})$} & $\mathrm{T7}$ & 80 & 21.09 & 29.8 & \\
\hline & T8a & 83.9 & 22.12 & 31.3 & \\
\hline & $\mathrm{T} 8 \mathrm{~b}$ & 16.2 & 4.27 & 6.0 & \\
\hline & T9 & 37.5 & 9.89 & 14.0 & 81.2 \\
\hline Acetone & T10 & 3 & 0.79 & 1.1 & 1.1 \\
\hline Recovery & & 268.1 & 70.68 & 100.0 & \\
\hline
\end{tabular}


Table S2. Flavan-3-ol subunit composition (molar percentages) of condensed tannins from sainfoin (Cotswold Common) separated on either Sephadex LH-20 or Toyopearl HW-50F columns (Method 2).

\begin{tabular}{|c|c|c|c|c|c|c|c|c|c|}
\hline \multirow{2}{*}{$\begin{array}{l}\text { Columns and eluents } \\
\text { Sephadex LH-20 }\end{array}$} & \multirow[t]{2}{*}{ Fraction } & \multicolumn{4}{|c|}{ Terminal units (\%) } & \multicolumn{4}{|c|}{ Extension units (\%) } \\
\hline & & $\mathrm{GC}$ & EGC & C & EC & $\mathrm{GC}$ & EGC & $\mathrm{C}$ & $\mathrm{EC}$ \\
\hline \multirow[t]{3}{*}{ Water } & S1 & - & - & $3.3(0.4)$ & $4.9(0.5)$ & - & $21.5(1.5)$ & - & $70.3(1.5)$ \\
\hline & S2 & - & - & $5.7(1.0)$ & $16.3(0.3)$ & - & $18.9(1.8)$ & - & $59.1(1.7)$ \\
\hline & S3 & - & - & $4.5(0.4)$ & $17.4(0.9)$ & - & $17.6(3.0)$ & - & $60.5(3.1)$ \\
\hline \multirow[t]{3}{*}{ Methanol/water $(1: 1, \mathrm{v} / \mathrm{v})$} & S4 & - & - & $4.2(0.6)$ & $13.6(0.3)$ & - & $19.3(0.1)$ & & $62.9(0.8)$ \\
\hline & S5 & - & - & $5.5(0.3)$ & $11.2(0.8)$ & - & $24.8(3.3)$ & - & $58.6(2.6)$ \\
\hline & S6 & - & - & 4.9 (1.9) & $9.0(0.2)$ & - & $20.3(2.9)$ & - & $65.9(1.5)$ \\
\hline \multirow[t]{4}{*}{ Acetone/water $(7: 3, \mathrm{v} / \mathrm{v})$} & S7 & $1.1(0.1)$ & $1.6(0.1)$ & $3.2(0.1)$ & $3.9(0.1)$ & $7.0(0.3)$ & $42.4(0.2)$ & $3.2(0.1)$ & $37.6(0.3)$ \\
\hline & S8a & $1.9(0.1)$ & $2.4(0.1)$ & $4.4(0.0)$ & $5.1(0.0)$ & $9.0(0.0)$ & $35.6(0.1)$ & $5.3(0.1)$ & $36.4(0.2)$ \\
\hline & S8b & $2.2(0.1)$ & $2.6(0.1)$ & $3.7(0.0)$ & $4.1(0.1)$ & $10.4(0.3)$ & $41.1(0.3)$ & $4.1(0.1)$ & $31.8(0.4)$ \\
\hline & S9 & $2.0(0.2)$ & $2.7(0.4)$ & $2.7(0.1)$ & $2.7(0.1)$ & $10.5(0.3)$ & $48.1(0.4)$ & $3.1(0.2)$ & $28.0(0.8)$ \\
\hline Acetone & S10 & $1.3(0.2)$ & $1.8(0.1)$ & $1.8(0.2)$ & $1.9(0.1)$ & $11.2(0.2)$ & $51.6(0.3)$ & $3.0(0.1)$ & $27.4(0.3)$ \\
\hline \multicolumn{10}{|l|}{ Toyopearl HW-50F } \\
\hline \multirow[t]{3}{*}{ Water } & $\mathrm{T} 1$ & - & - & $1.2(0.2)$ & $1.5(0.1)$ & $5.7(0.7)$ & $61.5(0.8)$ & $1.9(0.2)$ & $28.2(0.2)$ \\
\hline & $\mathrm{T} 2$ & - & - & - & - & - & - & - & $100(0.0)$ \\
\hline & T3 & - & - & - & - & - & - & - & - \\
\hline \multirow[t]{3}{*}{ Methanol/water $(1: 1, \mathrm{v} / \mathrm{v})$} & T4 & - & - & - & - & - & - & - & - \\
\hline & T5 & - & - & $8.5(0.8)$ & $12.0(0.9)$ & - & $10.4(4.3)$ & $6.6(0.8)$ & $62.5(1.9)$ \\
\hline & T6 & - & - & - & $10.9(2.8)$ & - & - & $6.3(0.3)$ & $82.8(3.0)$ \\
\hline \multirow[t]{4}{*}{ Acetone/water $(7: 3, \mathrm{v} / \mathrm{v})$} & T7 & $1.5(0.1)$ & $1.7(0.1)$ & $4.5(0.1)$ & $5.1(0.0)$ & $5.3(0.3)$ & $33.7(0.1)$ & $4.1(0.1)$ & $44.2(0.2)$ \\
\hline & $\mathrm{T} 8 \mathrm{a}$ & $1.7(0.2)$ & $2.1(0.2)$ & $3.2(0.1)$ & $3.9(0.1)$ & $9.6(0.1)$ & $44.8(0.4)$ & $4.1(0.1)$ & $30.7(0.1)$ \\
\hline & T8b & $1.0(0.0)$ & $1.3(0.2)$ & $0.9(0.0)$ & $1.2(0.0)$ & $11.2(0.3)$ & $70.7(0.3)$ & $1.5(0.1)$ & $12.3(0.1)$ \\
\hline & T9 & $0.5(0.1)$ & $0.4(0.1)$ & $0.5(0.0)$ & $0.5(0.0)$ & $9.8(0.4)$ & $77.9(0.5)$ & $0.9(0.1)$ & $9.4(0.2)$ \\
\hline Acetone & T10 & $0.5(0.1)$ & $0.5(0.1)$ & $0.6(0.0)$ & $0.7(0.1)$ & $9.2(0.2)$ & $75.2(0.1)$ & $1.3(0.0)$ & $12.1(0.1)$ \\
\hline
\end{tabular}

*) -: none detected

$\mathrm{GC}=$ gallocatechin, $\mathrm{EGC}=$ epigallocatechin, $\mathrm{C}=$ catechin, $\mathrm{EC}=$ epicatechin 
Table S3. Flavan-3-ol subunit compositions (molar percentages) of condensed tannin fractions obtained by wide Sephadex LH-20 column chromatography (Method 3). ( $n=1$ to 9 separate fractionations). Fractions were analyzed by thiolytic degradation.

\begin{tabular}{|c|c|c|c|c|c|c|c|c|}
\hline & \multicolumn{4}{|c|}{ Terminal units (\%) } & \multicolumn{4}{|c|}{ Extension units (\%) } \\
\hline & GC & EGC & C & EC & GC & EGC & $\mathrm{C}$ & EC \\
\hline \multicolumn{9}{|l|}{ Birdsfoot trefoil } \\
\hline$F 1(n=5)$ & - & - & $19.6(2.42)$ & $6.8(1.08)$ & - & $16.8(0.75)$ & $3.6(0.21)$ & $53.2(2.97)$ \\
\hline $\mathrm{F} 2(\mathrm{n}=4)$ & - & - & $5.9(0.93)$ & $2.1(0.36)$ & - & $33.0(2.46)$ & $3.0(0.13)$ & $56.0(1.14)$ \\
\hline F3 $(n=3)$ & - & - & $2.5(0.61)$ & $0.8(0.22)$ & - & $26.2(8.37)$ & $2.0(0.81)$ & $68.4(9.10)$ \\
\hline \multicolumn{9}{|l|}{ Big trefoil } \\
\hline$F 1(n=4)$ & - & - & $12.6(0.94)$ & $6.0(0.47)$ & $15.7(2.74)$ & $49.0(3.24)$ & $4.4(0.31)$ & $12.3(0.52)$ \\
\hline$F 2(n=4)$ & - & - & $4.0(0.23)$ & $1.6(0.11)$ & $8.5(0.08)$ & $66.6(0.55)$ & $3.0(0.06)$ & $16.3(0.22)$ \\
\hline \multicolumn{9}{|l|}{ Sericea lespedeza } \\
\hline$F 1(n=3)^{*}$ & $13.1(0.06)$ & $5.3(0.01)$ & $1.0(0.00)$ & $1.0(0.03)$ & $18.9(0.06)$ & $55.2(0.07)$ & $1.7(0.02)$ & $3.9(0.05)$ \\
\hline$F 2(n=3)^{*}$ & $5.8(0.18)$ & $2.1(0.00)$ & $0.4(0.00)$ & $0.6(0.20)$ & $17.0(0.06)$ & $67.5(0.39)$ & $1.6(0.02)$ & $5.1(0.03)$ \\
\hline F3 $(n=3)^{*}$ & $2.7(0.04)$ & $1.1(0.00)$ & $0.2(0.00)$ & $0.1(0.00)$ & $15.3(0.04)$ & $75.4(0.08)$ & $1.1(0.01)$ & $4.3(0.01)$ \\
\hline \multicolumn{9}{|l|}{ Crownvetch } \\
\hline$F 1(n=5)$ & $1.8(0.42)$ & $1.5(0.31)$ & $5.1(0.75)$ & $0.3(0.64)$ & $4.6(0.39)$ & $66.9(4.98)$ & $1.8(0.27)$ & $18.1(3.95)$ \\
\hline$F 2(n=5)$ & $1.2(0.08)$ & $1.0(0.11)$ & $3.5(0.35)$ & $1.7(0.21)$ & $5.4(0.10)$ & $66.3(0.86)$ & $1.8(0.07)$ & $19.1(0.31)$ \\
\hline F3 $(n=1)$ & 0.7 & 0.7 & 2.5 & 1.1 & 5.7 & 67.3 & 1.9 & 20.3 \\
\hline \multicolumn{9}{|l|}{ Tilia sp } \\
\hline $\mathrm{F} 1(\mathrm{n}=9)$ & - & - & $5.0(0.34)$ & $36.3(2.62)$ & - & $3.8(0.99)$ & $4.6(0.27)$ & $50.3(2.45)$ \\
\hline$F 2(n=9)$ & - & - & $1.8(0.15)$ & $14.9(0.73)$ & - & $3.0(1.03)$ & $2.7(0.16)$ & $77.7(1.13)$ \\
\hline \multicolumn{9}{|l|}{ Weeping willow } \\
\hline$F 1(n=2)$ & $0.72(1.02)$ & $2.54(0.28)$ & $18.8(0.98)$ & $12.9(0.19)$ & $9.66(0.88)$ & $12.4(0.44)$ & $14.4(0.49)$ & $28.7(0.39)$ \\
\hline$F 2(n=2)$ & $0.25(0.35)$ & $0.52(0.07)$ & $6.43(0.87)$ & $4.80(0.14)$ & $13.4(4.87)$ & $17.3(2.47)$ & $16.9(2.07)$ & $40.4(5.21)$ \\
\hline $\mathrm{F} 3(\mathrm{n}=1)$ & 1.29 & 1.32 & 2.90 & 1.84 & 16.7 & 22.5 & 10.3 & 43.1 \\
\hline \multicolumn{9}{|l|}{ Sainfoin } \\
\hline$F 1(n=2)$ & $8.93(0.30)$ & $12.1(2.14)$ & $6.59(0.83)$ & $7.42(0.66)$ & $15.1(1.05)$ & $33.1(0.36)$ & $3.08(1.15)$ & $13.7(2.53)$ \\
\hline$F 2(n=2)$ & $2.66(0.34)$ & $2.15(0.32)$ & $3.13(0.35)$ & $2.65(0.28)$ & $10.9(1.02)$ & $49.0(1.47)$ & $2.93(0.06)$ & $26.6(0.91)$ \\
\hline F3 $(n=1)$ & 2.32 & 1.88 & 2.75 & 2.35 & 10.5 & 50.7 & 2.78 & 26.7 \\
\hline
\end{tabular}

*) analytical replicates; “_" not detected; GC = gallocatechin, EGC = epigallocatechin, C = catechin, EC = epicatechin 
Table S4. Weight, purity and composition of condensed tannins (CT) from thiolysis degradation of replicate purified ( $\mathrm{n}=2)$ fractions of sainfoin $(2 \mathrm{~g}$ crude extract) using Sephadex LH-20 batch chromatography (Method 4) (SD from replicate fractionations in parentheses). ${ }^{\text {a }}$

\begin{tabular}{|c|c|c|c|c|c|c|}
\hline Solvent & Yield in grams & $\begin{array}{l}\text { Recovered weight \% } \\
\text { of applied sample }\end{array}$ & $\begin{array}{c}\% \mathrm{CT} \text { content } \\
\text { (g/100 g fraction) }\end{array}$ & $\mathrm{mDP}$ & $\mathrm{PC} / \mathrm{PD}$ & $\begin{array}{l}\text { cis/trans flavan-3- } \\
\text { ols }\end{array}$ \\
\hline 1:1 Methanol/water (F0) & $1.39(0.01)$ & 69.5 & $9(4)$ & & $7.0 / 93.0(0.7)$ & $91.3 / 8.7(0.9)$ \\
\hline 3:7 Acetone/water (F1) & $0.11(0.04)$ & 5.4 & $20(7)$ & $7.0(1.4)$ & $14.0 / 86.0(4.8)$ & $79.6 / 20.4(0.4)$ \\
\hline 1:1 Acetone/water (F2) & $0.22(0.06)$ & 10.7 & $96(8)$ & $16.8(1.0)$ & $12.6 / 87.4(0.5)$ & $85.0 / 15.0(1.4)$ \\
\hline 7:3 Acetone/water (F3) & $0.13(0.08)$ & 3.8 & $94(16)$ & $22.0(10.0)$ & $12.0 / 88.0(1.3)$ & $84.0 / 14.0(3.0)$ \\
\hline Recovery & 185 & 925 & & & & \\
\hline
\end{tabular}

${ }^{a} \% \mathrm{CT}$ content refers to purified fractions;

Abbreviations used: mDP: mean degree of polymerization; PC/PD: molar percentages of procyanidins/prodelphinidins; cis/trans: molar percentages of cis/trans flavan-3-ols. 
Table S5. Flavan-3-ol subunits (molar percentages) composition from fractionations purified once using Sephadex LH-20 batch chromatography (Method 4). Fractions were analyzed by thiolytic degradation for flavan-3-ol composition.

(SD is from replicate analytical analysis except that of goat willow which is from replicate fractionations)

\begin{tabular}{|c|c|c|c|c|c|c|c|c|c|c|}
\hline & \multirow[t]{2}{*}{ Plant species } & \multirow[t]{2}{*}{ Fraction } & \multicolumn{4}{|c|}{ Terminal units (\%) } & \multicolumn{4}{|c|}{ Extension units (\%) } \\
\hline & & & GC & EGC & $\mathrm{C}$ & EC & GC & EGC & C & EC \\
\hline 1 & Birdsfoot trefoil & F3 & - & - & $2.41(0.03)$ & $0.85(0.05)$ & $0.86(0.04)$ & $41.6(0.4)$ & $2.21(0.05)$ & $52.1(0.08)$ \\
\hline 2 & Big trefoil & F3 & $2.0(0.3)$ & $0.59(0.03)$ & $1.79(0.01)$ & $0.67(0.03)$ & $9.13(0.05)$ & $68.9(0.5)$ & $2.24(0.03)$ & $14.7(0.2)$ \\
\hline 3 & $\begin{array}{l}\text { HT } \\
\text { Mediterranean } \\
\text { trefoil }\end{array}$ & F3 & $0.5(0.01)$ & - & $1.98(0.03)$ & $0.13(0.01)$ & $1.26(0.1)$ & $67.0(0.07)$ & $1.94(0.02)$ & $24.7(0.1)$ \\
\hline & & & & & & & & & & \\
\hline 4 & Goat willow & $\mathrm{F} 2$ & $1.90(0.3)$ & $0.9(0.1)$ & $9.71(0.03)$ & $0.97(0.04)$ & $42.2(0.08)$ & $9.90(0.2)$ & $28.4(0.1)$ & $6.87(0.02)$ \\
\hline 5 & Goat willow & F3 & $1.75(0.09)$ & - & $5.89(0.013)$ & $0.61(0.05)$ & $44.1(0.3)$ & $13.0(0.3)$ & $26.2(0.01)$ & $8.45(0.01)$ \\
\hline 6 & Black currant & F2 & $1.8(0.1)$ & $1.30(0.07)$ & $1.01(0.01)$ & $1.01(0.02)$ & $13.83(0.04)$ & $13.06(0.05)$ & $1.46(0.02)$ & $0.78(0.06)$ \\
\hline 7 & Black currant & F3 & $5.3(0.3)$ & $0.7(0.1)$ & $0.60(0.01)$ & $0.05(0.06)$ & $66.9(0.1)$ & $24.1(0.1)$ & $1.30(0.02)$ & $1.06(0.06)$ \\
\hline
\end{tabular}

- not observed

$\mathrm{GC}=$ gallocatechin, $\mathrm{EGC}=$ epigallocatechin, $\mathrm{C}=$ catechin, $\mathrm{EC}=$ epicatechin 
Table S6. Flavan-3-ol subunits (molar percentages) composition from fractionations purified twice using Sephadex LH-20 batch chromatography (Method 4). Fractions were analyzed by thiolytic degradation for flavan-3-ol composition (SD is from replicate analytical analysis except that of HT Mediterranean which is from replicate fractionations).

\begin{tabular}{|c|c|c|c|c|c|c|c|c|c|c|}
\hline & \multirow[t]{2}{*}{ Plant species } & \multirow[t]{2}{*}{ Fraction } & \multicolumn{4}{|c|}{ Terminal units (\%) } & \multicolumn{4}{|c|}{ Extension units (\%) } \\
\hline & & & GC & EGC & C & EC & GC & EGC & $\mathrm{C}$ & EC \\
\hline 1 & Birdsfoot trefoil & P2F3 & - & - & $3.97(0.02)$ & $1.4(0.1)$ & $0.87(0.01)$ & $36.1(0.4)$ & $2.70(0.10)$ & $55.0(0.30)$ \\
\hline 2 & Big trefoil & $\mathrm{P} 2 \mathrm{~F} 3$ & $2.0(0.4)$ & $0.7(0.1)$ & $2.25(0.03)$ & $0.82(0.01)$ & $9.52(0.05)$ & $67.1(0.4)$ & $2.43(0.09)$ & $2.06(0.08)$ \\
\hline 3 & Big trefoil & P2F4 & $1.8(0.1)$ & $0.7(0.1)$ & $2.78(0.03)$ & $1.05(0.02)$ & $9.98(0.07)$ & $65.9(0.3)$ & $2.58(0.01)$ & $15.2(0.20)$ \\
\hline 4 & $\begin{array}{l}\text { Sericea } \\
\text { lespedeza }\end{array}$ & P2F3 & $4.9(0.8)$ & $1.52(0.05)$ & $0.23(0.00)$ & $0.30(0.5)$ & $13.5(0.2)$ & $73.7(0.6)$ & $0.74(0.01)$ & $5.13(0.02)$ \\
\hline 5 & $\begin{array}{l}\text { Sericea } \\
\text { lespedeza }\end{array}$ & P2F4 & $6.3(0.1)$ & $2.0(0.2)$ & $0.33(0.03)$ & $0.40(0.7)$ & $14.2(0.1)$ & $70.5(0.2)$ & $0.80(0.04)$ & $5.40(0.10)$ \\
\hline 6 & $\begin{array}{l}\text { HT } \\
\text { Mediterranean } \\
\text { trefoil }\end{array}$ & P2F3 (n=2) & $1.2(0.2)$ & - & $2.94(0.06)$ & $0.20(0.01)$ & $3.80(0.09)$ & $63.3(0.2)$ & $2.38(0.03)$ & $26.2(0.10)$ \\
\hline 7 & $\begin{array}{l}\text { HT } \\
\text { Mediterranean } \\
\text { trefoil }\end{array}$ & P2F4 (n=2) & $1.2(0.3)$ & - & $4.22(0.02)$ & $0.30(0.01)$ & $4.10(0.1)$ & $61.0(0.1)$ & $2.74(0.04)$ & $26.4(0.08)$ \\
\hline 8 & $\begin{array}{l}\text { White clover } \\
\text { flowers }\end{array}$ & $\mathrm{P} 2 \mathrm{~F} 3$ & $4.34(0.05)$ & $1.2(0.2)$ & - & - & $24.5(0.2)$ & $69.4(0.4)$ & $0.26(0.01)$ & $0.71(0.01)$ \\
\hline 9 & $\begin{array}{l}\text { White clover } \\
\text { flowers }\end{array}$ & P2F4 & $6.4(0.5)$ & $2.2(0.2)$ & - & - & $25.4(0.3)$ & $64.9(0.3)$ & $0.26(0.01)$ & $0.80(0.10)$ \\
\hline & & & & & & & & & & \\
\hline 10 & $\begin{array}{l}\text { Black currant } \\
\text { leaves }\end{array}$ & $\mathrm{P} 2 \mathrm{~F} 3$ & $5.45(0.02)$ & $0.49(0.08)$ & $0.62(0.03)$ & - & $12.3(0.3)$ & $18.5(0.1)$ & $1.26(0.01)$ & $0.75(0.01)$ \\
\hline 11 & $\begin{array}{l}\text { Black currant } \\
\text { leaves }\end{array}$ & P2F4 & $8.0(0.2)$ & $0.9(0.2)$ & $0.76(0.03)$ & - & $73.3(0.3)$ & $15.1(0.2)$ & $1.31(0.01)$ & $0.67(0.07)$ \\
\hline & & & & & & & & & & \\
\hline & & & & & & & & & & \\
\hline
\end{tabular}

- not observed

$\mathrm{GC}=$ gallocatechin, $\mathrm{EGC}=$ epigallocatechin, $\mathrm{C}=$ catechin, $\mathrm{EC}=$ epicatechin 
Table S7: Summary of conditions suited for isolating different CTs.

\begin{tabular}{|c|c|c|c|}
\hline $\begin{array}{c}\text { Method number \& } \\
\text { description }\end{array}$ & Conditions and fraction numbers & Pros & Cons \\
\hline $\begin{array}{l}\text { Method 1: } \\
\text { 'Standard Column' Toyopearl } \\
\text { HW-50F Chromatography }\end{array}$ & $\begin{array}{l}\text { 1. Aqueous acetone (7:3) extract: } 2 \mathrm{~g} \\
\text { 2. Column dimensions: } 230 \mathrm{~mm} \times 30 \mathrm{~mm} \\
\text { 3. Eluents and fractions: } \\
\text { - } \text { water }(300 \mathrm{~mL}) \\
\text { - } \text { methanol/water }(1: 1 ; 300 \mathrm{~mL}) \\
\text { - } \text { acetone/water }(7: 3 ; 3 \times 100 \mathrm{~mL}): \text { TF7, TF8 and } \\
\text { TF9 } \\
\text { - acetone }(100 \mathrm{~mL}): \text { TF10 }\end{array}$ & $\begin{array}{l}\text { 1. mDP: excellent size } \\
\text { separation mDP values of } 2 \text { to } \\
95 \\
\text { 2. PC/PD: some separation of } \\
\text { PCs from PDs }\end{array}$ & $\begin{array}{l}\text { 1. Yields: } 4 \mathrm{mg} \text { to } 184 \\
\text { mg } \\
\text { 2. CT purities: less } \\
\text { than }<60 \%\end{array}$ \\
\hline $\begin{array}{l}\text { Method 2: } \\
\text { 'Standard Column' } \\
\text { Chromatography on } \\
\text { Toyopearl HW-50F versus } \\
\text { Sephadex LH-20 }\end{array}$ & 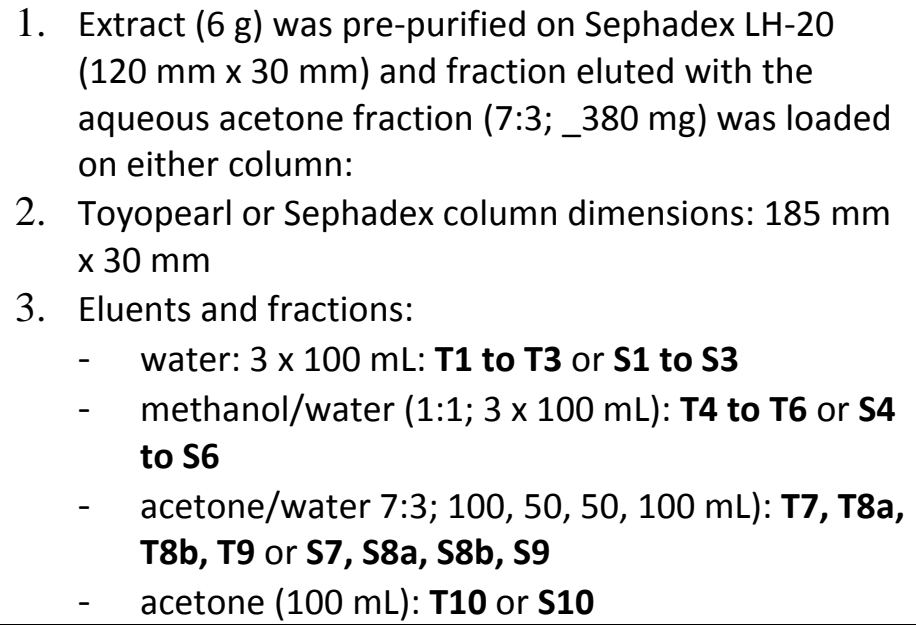 & $\begin{array}{l}\text { 1. CT purities of aqueous } \\
\text { acetone fraction: }>80 \% \\
\text { 2. Toyopearl HW-50F better } \\
\text { than Sephadex LH-20 at } \\
\text { separating CTs according to } \\
\text { mDP values and PC/PD ratios }\end{array}$ & $\begin{array}{l}\text { 1. Pre-purification } \\
\text { step essential to } \\
\text { achieve high CT } \\
\text { purities. } \\
\text { 2. Yields: } 3 \text { mg to } 119 \\
\text { mg } \\
\text { 3. Time needed: ca } 5 \\
\text { hours }\end{array}$ \\
\hline $\begin{array}{l}\text { Method 3: } \\
\text { 'Wide column' Sephadex LH- } \\
20 \text { Chromatography }\end{array}$ & $\begin{array}{l}\text { 1. Aqueous acetone (7:3) extract: } 10 \mathrm{~g} \\
\text { 2. Sephadex LH-20 (50 g) } \\
\text { 3. Column dimensions: } 70 \mathrm{~mm} \times 65 \mathrm{~mm} \\
\text { 4. Eluents and fractions: } \\
\text { - } \text { water ( } 2 \mathrm{~L}) \\
\text { - } \text { acetone/water (3:7): F1 } \\
\text { - acetone/water (1:1): F2 } \\
\text { - acetone/water (8:2): F3 }\end{array}$ & $\begin{array}{l}\text { 1. Yields of Fraction 1: } 146 \text { to } \\
800 \mathrm{mg} \text {; yields of Fraction } 2 \text { : } \\
174 \mathrm{mg} \text { to } 1200 \mathrm{mg} \\
\text { 2. CT purities of Fraction 2: } 64 \% \\
\text { to } 100 \% \\
\text { 3. mDP ranges: } 3 \text { to } 12 \text { (Fraction } \\
\text { 1); } 8 \text { to } 18 \text { (Fraction } 2 \text { ); } 14 \text { to } \\
\text { 30 (Fraction 3) }\end{array}$ & $\begin{array}{l}\text { 1. PC/PD ratios: little } \\
\text { separation of PCs } \\
\text { and PDs } \\
\text { 2. Fraction } 3 \text { gives } \\
\text { CTs with higher } \\
\text { mDP values but } \\
\text { low yields }\end{array}$ \\
\hline
\end{tabular}




\begin{tabular}{|c|c|c|c|}
\hline & & $\begin{array}{l}\text { 4. Time needed per run: } 4 \text { to } 5 \\
\text { hours } \\
\text { 5. Sephadex LH-20 ( } 50 \mathrm{~g}) \\
\text { column can be re-used up to } \\
10 \text { times }\end{array}$ & \\
\hline $\begin{array}{l}\text { Method 4: } \\
\text { 'Batch Chromatography' with } \\
\text { Sephadex LH-20. }\end{array}$ & $\begin{array}{l}\text { 1. Aqueous acetone extract: } 4.5 \mathrm{~g} \text { to } 19 \mathrm{~g} \\
\text { 2. Sephadex LH-20 (10 g per g of extract) } \\
\text { 3. Buchner filter funnel } 600 \text { or } 1500 \mathrm{~mL} \\
\text { 4. Eluents and fractions: } \\
\text { - methanol/water ( } 1: 1 ; 3 \times 5 \mathrm{~mL} / \mathrm{g} \text { Sephadex LH- } \\
\text { 20): F0 } \\
\text { - acetone/water }(3: 7 ; 3 \times 5 \mathrm{~mL} / \mathrm{g} \text { Sephadex LH-20): } \\
\text { - F1 } \\
\text { - acetone/water }(1: 1 ; 3 \times 5 \mathrm{~mL} / \mathrm{g} \text { Sephadex LH-20): } \\
\text { F2 } \\
\text { - acetone/water ( } 7: 3 ; 3 \times 5 \mathrm{~mL} / \mathrm{g} \text { Sephadex LH-20): } \\
\text { F3 }\end{array}$ & $\begin{array}{l}\text { 1. Yields of } \mathbf{F} \mathbf{3} \text { and } \mathbf{F} 4: 100 \mathrm{mg} \text { to } \\
1.23 \mathrm{~g} \\
\text { 2. CT purities: } 73 \text { to } 97 \% \\
\text { 3. mDP ranges: } 8 \text { to } 38 \\
\text { 4. Time needed per run: } 2.5 \\
\text { hours }\end{array}$ & $\begin{array}{l}\text { 1. Sephadex } L H-20 \text { is } \\
\text { used once }\end{array}$ \\
\hline
\end{tabular}




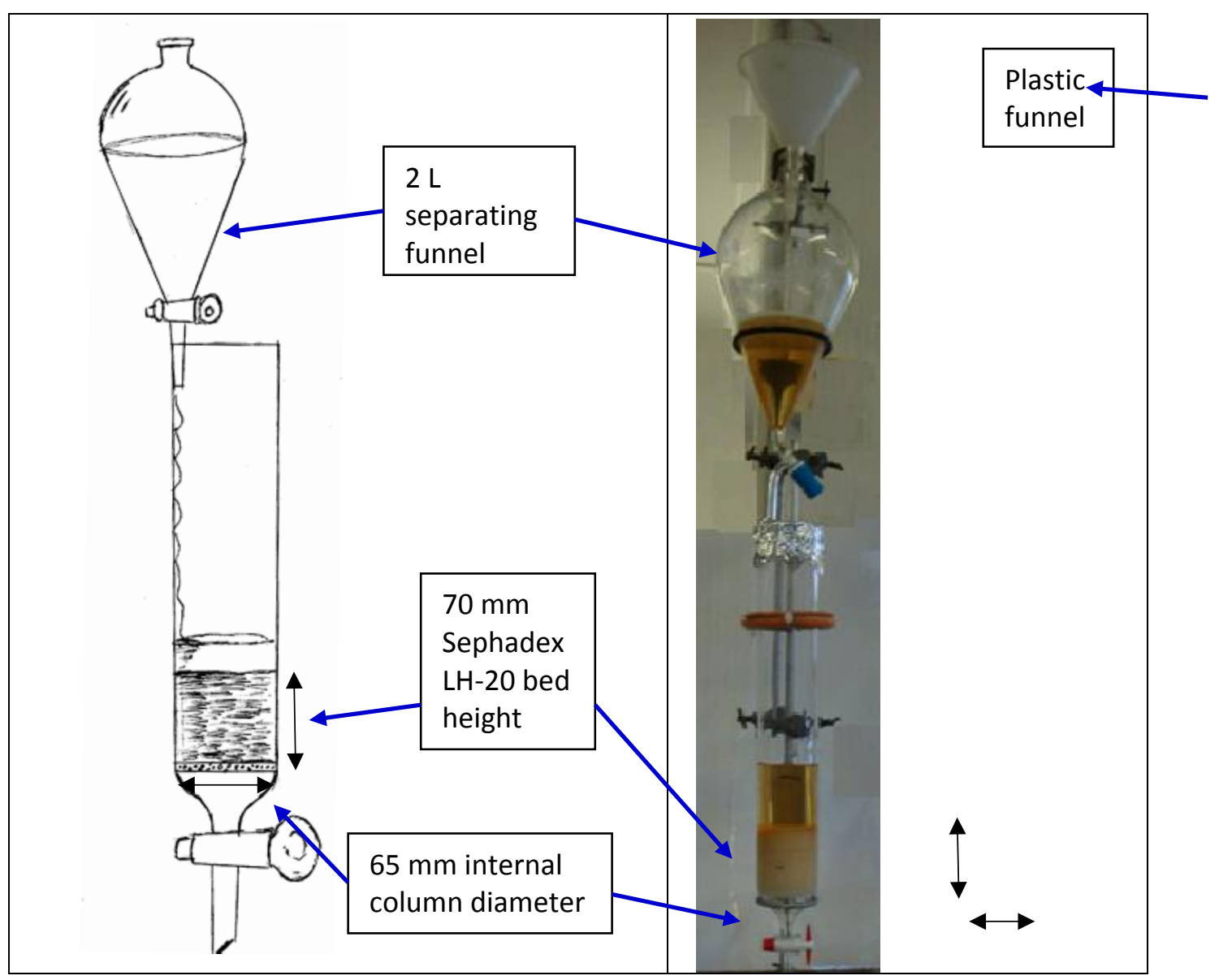

Figure S1. Set up for wide Sephadex LH-20 column fractionation (Method 3). 